\title{
Comparative Analysis of Alignments between SDG16 and the Other Sustainable Development Goals
}

\author{
Anthony Wakwe Lawrence ${ }^{1}$, Noel Ihebuzor ${ }^{2}, \&$ Damiete Onyema Lawrence ${ }^{3}$ \\ ${ }^{1}$ Chairman, Community Inter-Relations and Conciliation Initiative (CIRCI), Port Harcourt, Nigeria \\ ${ }^{2}$ Development Consultant, Evidentis Development Associates, Abuja, Nigeria \\ ${ }^{3} \mathrm{PhD}$ Student of Rivers State University, Port Harcourt, Nigeria \\ Correspondence: Anthony Wakwe Lawrence, Chairman, Community Inter-Relations and Conciliation Initiative \\ (CIRCI), Port Harcourt, Nigeria.
}

Received: August 10, 2020

Accepted: August 31, 2020

Online Published: September 4, 2020

doi:10.5539/ibr.v13n10p13

URL: https://doi.org/10.5539/ibr.v13n10p13

\begin{abstract}
SDG16 cuts through, affects and is affected by the other 16 SDGs. This study involved a number of steps; the first step was computing the degrees of compatibility/alignments of SDG16 targets as individual targets against the targets of the other 16 SDGs using a scoring system that ranged from -3 to +3 . The next step in data treatment involved computing the means for each row in each table to get the compatibility scores between SDG16 targets and each goal and then we used the columns to compare the SDG16 with the targets of each of the other goals. The final steps involved computing the mean compatibility scores between the SDG16 goal and the goals of the other SDGs on one hand and those between the SDG16 targets and the other 16 SDGs on the other. The approach is based on the strategic management principle that objectives and targets are set in ways that their achievement help in the achievement of the aspirations of the goal. The study approach is new, and it has not been done before. The compatibility examination showed that the aspirations embedded in the development of SDG2 (Zero Hunger) targets and those of SDG16 were least aligned and do not effectively support each other. SDG16 and SDG5 (Gender equality) were the most aligned, suggesting that the achievement of the SDG16 targets go a long way in supporting the achievement of SDG5 targets. An approach like this can be used as stand alone or in conjunction with the often used qualitative methods and will be a very helpful tool during SDG or related reviews, as it is useful in identifying targets and goals with high mutual transfer benefits among themselves. The study concludes with some recommendations.
\end{abstract}

Keywords: alignments, compatibility-score, complementary, scoring-system, Sustainable Development Goal (SDG)

\section{Introduction}

Recognition of the importance of SDG16 in the Agenda 2030 justifies the examination of the relationships between the building blocks of this SDG (the targets) and the building blocks (the targets) of the other 16 SDGs. It is expected that where the targets are aligned and are supportive of each other, then goals will be more effectively achieved. The approach is based on the strategic management principle that objectives and targets are set in ways that their achievement help in the achievement of the aspirations of the goal. The current study seeks to undertake such an examination using SDG16 as a test case to evaluate the effectiveness of the protocol developed for this study.

At the expiration of the Millennium Development Goals (MDGs), the 17 Sustainable Development Goals were developed in 2015 to further enhance a world that would be characterized by sustainable development with an eye on environmental protection, enhancing peace, ensuring justice, and promoting amity amongst the nations of the world. SDG policy formulators equally provided for regular and systematic assessments of performances along these 17 agreed goals. Since the launch of the SDGs in 2015, different scholars have worked on different areas of these SDGs and increasingly scholars are now beginning to pay attention to the relationships between these goals.

These studies in unearthing relationships between the SDGs reflect the growing recognition of the importance of such relationships in ensuring greater effectiveness and efficiency in implementing the SDGs. This importance of 
research that is driven by such recognition of SDG relationships is reinforced by the UNDP (2017) in its review of bottlenecks and accelerators in SDG implementation. "With the SDGs, the question is: What are the actions that will take us forward more quickly across a broader range of interlinked goals? Gap analysis may bring some value and sector-specific expertise on each of the goals is still required. But addressing the question requires thinking through the connections and synergies across the goals and highlighting how action in one area draws dividends in others and what the trade-offs are" (UNDP 2017 p 5).

There have been several works on the qualitative comparison or assessment of individual SDG targets or goals against the targets of other SDGs in terms of compatibility and possible synergy of target or goal aspirations. Such works that have examined the relationships of SDGs are indicative of the appreciation that some level of inter-relationships/alignments is needed between the targets/goals with those of the other targets/goals in the formulation of the SDGs if the SDGs are to remain faithful to the holism that informed their conception. These studies have used qualitative assessments to show the interrelatedness of the SDGs intricately and graphically (International Council for Science Union [ICSU] (2015); Nilsson, Griggs \& Visbeck, 2016, Lawrence, Ihebuzor \& Lawrence, 2020)).Their findings are that the SDGs are formulated in a way that many of them are directly or indirectly interrelated.

However, only few studies have adopted a quantitative methodology to assess the degree of relationship between a goal and the targets of one SDG to the targets of other SDGs. As stated earlier, the initial studies of relationships among the SDGs were done using mainly qualitative approaches which involved comparing goals and targets to find out to what extent they have structural or semantic resemblances to other targets and goals of other SDGs. This line of pursuit, useful as it was, had the challenge of how to quantitatively assess relationships. Subsequently in response to this challenge, Nilsson et al (2016) and others introduced scoring. Such an approach using scores then enabled the researchers to come up with metrics which revealed the strength of the relationship between some of the SDGs and their targets. The data that emerged from such an approach, for instance, indicated numerically the size of such relationships which ranged from marginal, zero or negative relationships. The current study is an extension of this approach.

The current research focused on SDG16, an SDG with vital social, ethical and economic import and focus. Literature is replete with recognition of the importance of SDG16 in relation to other SDGs. The quotation below is a good example.

"SDG16 is key to achieving the transformative 2030 Agenda. Its focus on seven tenets of strong institutions (effective, inclusive, responsive, participative, representative, accountable and transparent), as well as peaceful societies, are necessary for achieving all SDGs. This is true whether the goal is related to education, health, economic growth, climate change or beyond. Without sustained peace, which goes beyond the mere absence of violence and includes respect for human rights and the rule of law, development gains are reversed. And without inclusion and access to justice for all, inequalities in poverty reduction and socio-economic development will increase and countries' commitments to leaving no one behind will not be met" (UNDP, 2019; p20)

Using this SDG, the researchers assessed the degree of compatibility and alignment between its targets (SDG16) with the targets of the other 16 SDGs. and statistically computed the compatibility factors of the SDG16 targets as individual targets and as a goal to those of the targets and goals of the other 16 SD Goals.

For ease of processing and recall, the 17 SDGs are presented in Table 1 below. 
Table 1: Showing the Titles of the Sustainable Development Goals

\begin{tabular}{|c|l|}
\hline SDG & SUSTAINABLE DEVELOPMENT GOALS DESCRIPTION \\
\hline 1 & End poverty in all its forms everywhere \\
\hline 2 & End hunger, achieve food security and improved nutrition and promote sustainable agriculture \\
\hline 3 & Ensure healthy lives and promote well-being for all at all ages \\
\hline 4 & Ensure inclusive and equitable quality education and promote lifelong learning opportunities for all \\
\hline 5 & Achieve gender equality and empower all women and girls \\
\hline 6 & Ensure availability and sustainable management of water and sanitation for all \\
\hline 7 & Ensure access to affordable, reliable, sustainable and modern energy for all \\
\hline 8 & Promote sustained, inclusive and sustainable economic growth, full and productive employment and decent work for all \\
\hline 9 & Build resilient infrastructure, promote inclusive and sustainable industrialization and foster innovation \\
\hline 10 & Reduce inequality within and among countries \\
\hline 11 & Make cities and human settlements inclusive, safe, resilient and sustainable \\
\hline 12 & Ensure sustainable consumption and production patterns \\
\hline 13 & Take urgent action to combat climate change and its impacts \\
\hline 14 & Conserve and sustainably use the oceans, seas and marine resources for sustainable development \\
\hline 15 & $\begin{array}{l}\text { Protect, restore and promote sustainable use of terrestrial ecosystems, sustainably manage forests, combat desertification, } \\
\text { and halt and reverse land degradation and halt biodiversity loss }\end{array}$ \\
\hline 16 & $\begin{array}{l}\text { Promote peaceful and inclusive societies for sustainable development, provide access to justice for all and build effective, } \\
\text { accountable and inclusive institutions at all levels }\end{array}$ \\
\hline 17 & Strengthen the means of implementation and revitalize the global partnership for sustainable development \\
\hline
\end{tabular}

Source: United Nations [UN], 2020)

\section{THE SDG16 AND TARGETS}

Table 2: Showing the Targets of the Sustainable Development Goal 16

\begin{tabular}{|l|l|}
\hline SDG 16 TARGETS & \\
\hline T16.1 & Significantly reduce all forms of violence and related death rates everywhere. \\
\hline T16.2 & End abuse, exploitation, trafficking and all forms of violence against and torture of children. \\
\hline T16.3 & $\begin{array}{l}\text { Promote the rule of law at the national and international levels and ensure equal access to justice for } \\
\text { all }\end{array}$ \\
\hline T16.4 & $\begin{array}{l}\text { By 2030, significantly reduce illicit financial and arms flows, strengthen the recovery and return of } \\
\text { stolen assets and combat all forms of organised crime. }\end{array}$ \\
\hline T16.5 & Substantially reduce corruption and bribery in all their forms \\
\hline T16.6 & Develop effective, accountable and transparent institutions at all levels \\
\hline T16.7 & Ensure responsive, inclusive, participatory and representative decision-making at all levels. \\
\hline T16.8 & $\begin{array}{l}\text { Broaden and strengthen the participation of developing countries in the institutions of global } \\
\text { governance. }\end{array}$ \\
\hline T16.9 & By 2030, provide legal identity for all, including birth registration. \\
\hline T16.10 & $\begin{array}{l}\text { Ensure public access to information and protect fundamental freedoms, in accordance with national } \\
\text { legislation and international agreements. }\end{array}$ \\
\hline T16.A & $\begin{array}{l}\text { Strengthen relevant national institutions, including through international cooperation, for building } \\
\text { capacity at all levels, in particular in developing countries, to prevent violence and combat terrorism } \\
\text { and crime. }\end{array}$ \\
\hline T16.B & \begin{tabular}{l} 
Promote and enforce non-discriminatory laws and policies for sustainable development. \\
\hline Source
\end{tabular} \\
\hline
\end{tabular}

Source: United Nations [UN], 2020

\section{Literature Review}

The 2030 Agenda stated and is premised on the need for inter-linkages and interactions among the SDGs. The agenda also stressed the necessity and importance of looking at the SDGs holistically as an "indivisible whole". This quest and need for a holistic approach, has however thrown up a research and policy analysis challenge regarding how to think systematically about interactions across the SDGs (Nilsson et al 2016). The SDGs are 
replete with good illustrations of the strategic intentions by the SDG formulators on the importance of recognizing and maintaining connections between the various elements of development. Such a quality in the SDGs is commendable (Griggs et al., 2014; Lawrence et al., 2020).

Griggs et al. (2014) claimed that the SDGs are set in a way that individual goals though addressing a specific set or groups of challenges are equally interrelated in addressing other challenges. Such inter-relationships underscore the centrality of systems thinking to any proper treatment of the issue of development in general and the SDGs in particular (Lawrence et al, 2020). Senge (1990) defines it thus 'Systems thinking is a framework for seeing interrelationships rather than things, for seeing patterns rather than static snapshots. It is a set of general principles spanning fields as diverse as physical and social sciences, engineering, and management.

Previous studies of the relationships and compatibilities between the SDGs have come up with findings that whereas most relationships are positive, some could turn out to be negative if due attention is not paid to interactions at the implementation level (Nilsson et al., 2016).

Also, ICSU (2017), which examined interaction and relationships between some SDGs revealed that in the total of 316 interactions connected to SDG 2, 3, 7 and 14, 80\% of them were positive and 20\% were negative - their assessment focused on key interactions between selected SDGs from an expert-based assessment of interactions at goal level and their targets. Consequently, Weitz, Carlsen, Nilsson \& Skånberg (2017), on the basis of their examination of over 1000 interactions, assessed over 50\% of these interactions as neutral, and less than 5\% as negative. Notwithstanding, their findings raised the possibility of unintended outcomes, where the pursuit of one target could turn out to negatively impact the pursuit and attainment of other objectives, especially at the implementation level. Activities and actions at the implementation, monitoring and evaluation levels must, therefore, be on the lookout for such unintended outcomes.

In 2016, an international research initiative was taken to advance the theoretical and practical basis for understanding interactions. The SDG interaction framework was developed (Nilsson et al, 2016) and subsequently adopted by some international organizations and government. The interactions between SDGs have been limited to either the presence of a link, an identification of trade-off or synergy (McCollum, Echeverri, Busch, Pachauri, Parkinson, Rogelj, Krey, Minx, Nilsson, Stevance, 2018). Accordingly, Nilsson et al, (2016) framework is a typology and scoring of interactions on a 7-point scale, where the interaction label ranges from +3 to -3 and "its meaning goes from progress on one target automatically delivers progress on another" to "progress on one target automatically leads to a negative impact on another". A case in point could be the pursuit of, say SDGs 9, 11, 12, 13, 14 and 15 could result in conflicts and unintended negative impacts. Improved urban transportation could result, for example, in greater green-house gas emissions and an effect on urban air quality. The possibility of such interactions and their unintended consequences underscores the need for studies into SDG compatibilities as the findings could then inform areas where development planners could focus on leveraging co-benefits between their goals and targets, in the example provided between the pursuit of urban air quality, transport, housing, climate change and health (McCollum et al, 2018). The current study carries such awareness on board in its thinking and approach.

\section{Methodology}

The researchers approached the study from three perspectives:

1. The first part of the study involved using a seven-point scale $(-3$ to +3$)$ developed by Nilsson et al, (2016) to assess the level of compatibility and strength of relationships between the SDG16 targets with the targets of the remaining 16 SDGs.

2. The second part of the study involved using the means of the collated scores between SDG16 targets with each of the targets of the other 16 SDGs (as shown in the various tables for SDG1 to SDG17) to evaluate the level of compatibility between SDG16 targets with each of the other 16 Sustainable Development Goals.

3. The last part evaluates the derived cumulative means of the 12 SDG16 targets for each of the other 16 SDGs and compared the derived compatibility scores of these respective means of the 16 SDGs.

For step 1, the researchers sought to determine the extent to which the phrasing of the objectives/targets for SDG16, relate to the achievement of the aspirations of the other targets of the other goals. This step was taken to help the researchers uncover how strategically aligned the wordings of each of the SDG16 targets were to the targets of the other 16 SDGs and through that, to infer the facilitative effect that the achievement of each target could have on the achievement of the other targets of the other SDGs. This was with a view to test the claim that the SDGs are integrated and mutually reinforcing in their goals and targets, such that the achievement of a 
particular target must not only support the key aspects of the goal but must also facilitate the achievement of the goals and targets of the other SDGs. The greater this facilitative effect, the greater would be the synergy and benefits to attainment of the other SDGs. As explained earlier, a 7-point compatibility scoring scale was used to assess each of the 12 SDG16 targets against the remaining 157 targets of the 16 other SDGs using separate tables representing each SDG. Essentially, the first leg of our methodology adopted the one developed by Nilsson et al (2016), whose scoring scale is shown in the table below. It will be recalled that Nilsson et al adopted a scoring scale similar to a semantic differential with a seven-point scale with Zero showing no links, 3 showing very close additive links and -3 showing very negative and subtractive links.

Table 3: Showing the Seven Types of Interactions Between SDG Targets

\begin{tabular}{|c|l|l|}
\hline $\begin{array}{l}\text { Interaction } \\
\text { Label }\end{array}$ & Meaning & Implication \\
\hline+3 & $\begin{array}{l}\text { Progress on one target automatically } \\
\text { delivers progress on another }\end{array}$ & There is high level of compatibility between the two targets. \\
\hline+2 & $\begin{array}{l}\text { Progress on one target makes it easier to } \\
\text { make progress on another }\end{array}$ & $\begin{array}{l}\text { There is relatively higher level of compatibility between the } \\
\text { targets being compared. }\end{array}$ \\
\hline+1 & $\begin{array}{l}\text { Progress on one target creates conditions } \\
\text { that enable progress on another }\end{array}$ & $\begin{array}{l}\text { There is small level of compatibility between the two ta } \\
\text { compared }\end{array}$ \\
\hline 0 & $\begin{array}{l}\text { There is no significant link between two } \\
\text { targets' progress }\end{array}$ & $\begin{array}{l}\text { There is no significant compatibility between the two targets } \\
\text { being evaluated }\end{array}$ \\
\hline-1 & $\begin{array}{l}\text { Progress on one target constrains the } \\
\text { options for how to deliver on another }\end{array}$ & $\begin{array}{l}\text { The targets are relatively competitive resulting in } \\
\text { counterproductive effects }\end{array}$ \\
\hline-3 & $\begin{array}{l}\text { Progress on one target makes it more } \\
\text { difficult to make progress on another }\end{array}$ & $\begin{array}{l}\text { The targets are counterproductive and do not support each } \\
\text { other, } \\
\text { to a negative impact on another }\end{array}$ \\
\hline
\end{tabular}

Table 3 Source: Nilsson et al (2016). Implications were conceptualized by authors to further explain the meaning as developed by Nilsson et al (2016).

The quantitative approach adopted here starts with a painstaking comparison and allocation of scores based on the level of complementarity of every target of SDG16 to all the targets of the other SDGs (see Tables 4 to 19). Based on the strategic assumption that well-conceived and implemented targets holistically will help the achievement of the overarching goal, the cumulative total scores and means can be indicative of how well aligned the targets of SDG are helping in achieving the goals and how relatively aligned each goal is to the other goals. The total complementarity scores of the cells making up each column of each table were added up and divided by the number of observations to get the means, which gives indications of the level of complementarity between the SDG16 targets and the various targets of the other SDGs, each table represented information on one of the SDGs. The means of each column are shown in blue colours. On the other hand, the total complementarity scores of the cells making up each row for each table were added up and divided by the number of observations to get the means, which give indications of the level of complementarity between the various SDG16 targets with the cumulative mean for that SDG represented by the relevant table (figures coloured red).

Table 20 is the summary of the information derived from Tables 4 to 19 as explained above. Further, following the same approach above, the means in Table 20 for each column and each row were collated and data used to develop the information in figures 1 and 2. Figure 1 evaluated the compatibility values of the SDG16 as a goal to the other goals and Figure 2 evaluated the compatibility values of SDG16 targets to cumulative effects on all the other 16 SDGs.

We invited 10 persons with in-depth general knowledge of the Sustainable Development goals to do the compatibility scoring and then we totalled the observations (scores) to give the means which were then used to derive the information as shown from Table 4 to Table 19.

This method is different from the work by Lawrence et al (2020) who used qualitative methods to evaluate the direct and indirect relations between SDG4 and the other 16 SDGs.

The advantage of this method is that it starts with the assessment of each target of a goal to all the other targets of the other goals and then using the means collated for each goal to again assess how these targets relate (this time) to the overall and cumulative aspirations of other 16 SD goals (as expressed in their respective targets) and 
finally, how the goal (expressed in the cumulative compatibility mean scores of the targets) relates to the other 16 SDGs. We believe that this new approach is a useful way to evaluate targets and goal compatibilities of complex strategic policies like the SDGs.

\section{Findings/Discussion}

4.1 Evaluation Scores of SDG16 Targets with the Targets of the Other 16 SDGS in Terms of Their Compatibility and Alignments (Tables 4 To 19)

Table 4: Showing the Compatibility Scores of SDG16 Targets with SDG1 Targets

\begin{tabular}{|c|c|c|c|c|c|c|c|c|c|}
\hline \multirow{2}{*}{$\begin{array}{c}\text { SDG 16 } \\
\text { TARGETS }\end{array}$} & \multicolumn{7}{|c|}{ SDG 1 TARGETS } & \multirow{2}{*}{ MEAN } & \multirow[b]{2}{*}{ SD } \\
\hline & T1.1 & T1.2 & T1.3 & T1.4 & T1.5 & T1.A & T1.B & & \\
\hline T16.1 & 1 & 1 & 1 & 1 & 1 & 1 & 1 & 1.00 & 0.00 \\
\hline T16.2 & 1 & 2 & 1 & 1 & 1 & 1 & 1 & 1.14 & 0.38 \\
\hline T16.3 & 1 & 1 & 1 & 2 & 1 & 1 & 1 & 1.14 & 0.38 \\
\hline T16.4 & 1 & 1 & 1 & 0 & 1 & 1 & 1 & 0.86 & 0.38 \\
\hline T16.5 & 1 & 1 & 0 & 0 & 0 & 0 & 0 & 0.29 & 0.49 \\
\hline T16.6 & 1 & 1 & 1 & 1 & 1 & 1 & 1 & 1.00 & 0.00 \\
\hline T16.7 & 0 & 1 & 1 & 2 & 0 & 1 & 1 & 0.86 & 0.69 \\
\hline T16.8 & 0 & 1 & 1 & 0 & 1 & 0 & 1 & 0.57 & 0.53 \\
\hline T16.9 & 0 & 0 & 0 & 1 & 0 & 1 & 0 & 0.29 & 0.49 \\
\hline T16.10 & 0 & 1 & 1 & 3 & 1 & 0 & 1 & 1.00 & 1.00 \\
\hline T16.A & 0 & 1 & 1 & 1 & 1 & 1 & 1 & 0.86 & 0.38 \\
\hline T16.B & 0 & 1 & 1 & 3 & 1 & 1 & 1 & 1.14 & 0.90 \\
\hline MEAN & 0.50 & 1.00 & 0.83 & 1.25 & 0.75 & 0.75 & 0.83 & 0.85 & $\begin{array}{l}\text { SDG16 } \\
\mathrm{t}=-24.44 \\
\mathrm{p}=0.00\end{array}$ \\
\hline SD & 0.52 & 0.43 & 0.39 & 1.06 & 0.45 & 0.45 & 0.39 & 0.59 & $\begin{array}{c}\text { SDG1 } \\
\mathrm{t}=-24.48 \\
\mathrm{p}=0.00\end{array}$ \\
\hline
\end{tabular}

The highest mean score (highest level of compatibility) for SDG16 as a goal compared to the SDG1 targets was for SDG1 Target 4 at $1.25 \pm 1.06$. On the other hand, comparing SDG1 as a goal to the targets of SDG16, SDG16 Targets 2 and 3 scored $1.14 \pm 0.38$ respectively; this score was the highest and therefore the most compatible SDG16 targets with SDG1. When the one sample t-test was computed with a test value of +3 , the SDG16 had a mean significantly differed from the test value $(\mathrm{t}=24.44, \mathrm{p}=0.00)$ and a similar result was obtained for SDG1 which had a significant difference from the test value $(\mathrm{t}=24.48, \mathrm{p}=0.00)$.

Table 5: Showing the Compatibility Scores of Sdg16 Targets with SDG2 Targets

\begin{tabular}{|c|c|c|c|c|c|c|c|c|c|}
\hline \multirow{2}{*}{$\begin{array}{c}\text { SDG16 } \\
\text { TARGETS }\end{array}$} & \multicolumn{7}{|c|}{ SDG2 TARGETS } & \multirow{2}{*}{$\begin{array}{c}\text { MEAN } \\
\text { SCORE }\end{array}$} & \multirow[t]{2}{*}{ SD } \\
\hline & T2.1 & T2.2 & T2.3 & T2.4 & T2.5 & T2.A & T2.B & & \\
\hline T16.1 & 1 & 1 & 0 & 0 & 0 & 0 & 0 & 0.29 & 0.49 \\
\hline T16.2 & 0 & 1 & 0 & 0 & 0 & 0 & 0 & 0.14 & 0.38 \\
\hline T16.3 & 0 & 1 & 0 & 0 & 0 & 0 & 0 & 0.14 & 0.38 \\
\hline T16.4 & 0 & 0 & 0 & 0 & 0 & 0 & 0 & 0.00 & 0.00 \\
\hline T16.5 & 0 & 0 & 0 & 0 & 0 & 0 & 1 & 0.14 & 0.38 \\
\hline T16.6 & 0 & 0 & 1 & 0 & 0 & 1 & 1 & 0.43 & 0.53 \\
\hline T16.7 & 0 & 0 & 1 & 1 & 1 & 0 & 1 & 0.57 & 0.53 \\
\hline T16.8 & 0 & 1 & 0 & 0 & 1 & 0 & 1 & 0.43 & 0.53 \\
\hline T16.9 & 0 & 0 & 0 & 0 & 1 & 0 & 1 & 0.29 & 0.49 \\
\hline T16.10 & 0 & 1 & 1 & 1 & 1 & 0 & 1 & 0.71 & 0.49 \\
\hline T16.A & 0 & 0 & 0 & 0 & 0 & 0 & 1 & 0.14 & 0.38 \\
\hline T16.B & 1 & 1 & 1 & 1 & 1 & 1 & 1 & 1.00 & 0.00 \\
\hline MEAN & 0.17 & 0.50 & 0.33 & 0.25 & 0.42 & 0.17 & 0.67 & 0.36 & $\begin{array}{l}\text { SDG16 } \\
t=-31.68 \\
p=0.00\end{array}$ \\
\hline SD & 0.39 & 0.52 & 0.49 & 0.45 & 0.51 & 0.39 & 0.49 & 0.48 & $\begin{array}{l}\text { SDG2 } \\
t=-37.86 \\
p=0.00\end{array}$ \\
\hline
\end{tabular}


The highest mean score (highest level of compatibility) for SDG16 as a goal compared to the SDG2 targets was for SDG2 Target B at $0.67 \pm 0.49$. On the other hand, comparing SDG2 as a goal to the targets of SDG 16, SDG16 Target B scored 1.0 \pm 0.00 which was the highest and therefore the most compatible SDG16 targets with SDG2. When the one sample t-test was computed with a test value of +3 , the SDG16 had a mean significantly differed from the test value $(\mathrm{t}=31.68, \mathrm{p}=0.00)$ and a similar result was obtained for SDG2 which had a significant difference from the test value $(\mathrm{t}=37.86, \mathrm{p}=0.00)$.

Table 6: Showing the Compatibility Scores of SDG16 Targets with SDG3 Targets

\begin{tabular}{|c|c|c|c|c|c|c|c|c|c|c|c|c|c|c|c|}
\hline \multirow{3}{*}{$\begin{array}{c}\text { SDG16 } \\
\text { TARGET } \\
\text { S }\end{array}$} & \multirow{2}{*}{\multicolumn{13}{|c|}{$\begin{array}{c}\text { SDG3 TARGETS } \\
\text { T.3 }\end{array}$}} & \multirow{3}{*}{$\begin{array}{c}\text { MEAN } \\
\text { SCOR } \\
\text { E }\end{array}$} & \multirow{3}{*}{ SD } \\
\hline & & & & & & & & & & & & & & & \\
\hline & 1 & 2 & 3 & 4 & 5 & 6 & 7 & 8 & 9 & $\mathbf{A}$ & B & C & D & & \\
\hline T16.1 & 2 & 1 & 1 & 1 & 2 & 2 & 1 & 1 & 2 & 1 & 0 & 0 & 2 & 1.23 & 0.73 \\
\hline T16.2 & 1 & 2 & 1 & 1 & 2 & 1 & 2 & 1 & 2 & 0 & 0 & 1 & 2 & 1.23 & 0.73 \\
\hline T16.3 & 1 & 2 & 1 & 0 & 2 & 2 & 1 & 2 & 2 & 1 & 0 & 1 & 2 & 1.31 & 0.75 \\
\hline T16.4 & 2 & 1 & 0 & 0 & 2 & 0 & 0 & 0 & 2 & 0 & 0 & 2 & 2 & 0.85 & 0.99 \\
\hline T16.5 & 0 & 0 & 0 & 0 & 0 & 0 & 0 & 0 & 1 & 0 & 0 & 1 & 2 & 0.31 & 0.63 \\
\hline T16.6 & 2 & 2 & 2 & 2 & 2 & 1 & 2 & 2 & 2 & 2 & 1 & 2 & 3 & 1.92 & 0.49 \\
\hline T16.7 & 2 & 1 & 1 & 1 & 1 & 1 & 2 & 1 & 1 & 1 & 0 & 1 & 1 & 1.08 & 0.49 \\
\hline T16.8 & 1 & 1 & 1 & 1 & 1 & 1 & 2 & 1 & 1 & 1 & 1 & 2 & 2 & 1.23 & 0.44 \\
\hline T16.9 & 0 & 0 & 0 & 0 & 1 & 1 & 2 & 1 & 0 & 0 & 0 & 0 & 0 & 0.38 & 0.65 \\
\hline T16.10 & 2 & 2 & 2 & 2 & 2 & 1 & 1 & 2 & 1 & 1 & 1 & 2 & 1 & 1.54 & 0.52 \\
\hline T16.A & 2 & 1 & 1 & 1 & 1 & 1 & 1 & 1 & 1 & 1 & 1 & 1 & 1 & 1.08 & 0.28 \\
\hline T16.B & 2 & 2 & 2 & 2 & 1 & 1 & 2 & 2 & 2 & 1 & 0 & 2 & 1 & 1.54 & 0.66 \\
\hline MEAN & $\begin{array}{c}1.4 \\
2\end{array}$ & $\begin{array}{c}1.2 \\
5\end{array}$ & $\begin{array}{c}1.0 \\
0\end{array}$ & $\begin{array}{c}0.9 \\
2\end{array}$ & $\begin{array}{c}1.4 \\
2\end{array}$ & $\begin{array}{c}1.0 \\
0\end{array}$ & $\begin{array}{c}1.3 \\
3\end{array}$ & $\begin{array}{c}1.1 \\
7\end{array}$ & $\begin{array}{c}1.4 \\
2\end{array}$ & $\begin{array}{c}0.7 \\
5\end{array}$ & $\begin{array}{c}0.3 \\
3\end{array}$ & $\begin{array}{c}1.2 \\
5\end{array}$ & $\begin{array}{c}1.5 \\
8\end{array}$ & 1.14 & $\begin{array}{l}\text { SDG16 } \\
\mathrm{t}=-13.9 \\
6 \\
\mathrm{p}=0.00\end{array}$ \\
\hline SD & $\begin{array}{c}0.7 \\
9\end{array}$ & $\begin{array}{c}0.7 \\
5\end{array}$ & $\begin{array}{c}0.7 \\
4\end{array}$ & $\begin{array}{c}0.7 \\
9\end{array}$ & $\begin{array}{c}0.6 \\
7\end{array}$ & $\begin{array}{c}0.6 \\
0\end{array}$ & $\begin{array}{c}0.7 \\
8\end{array}$ & $\begin{array}{c}0.7 \\
2\end{array}$ & $\begin{array}{c}0.6 \\
7\end{array}$ & $\begin{array}{c}0.6 \\
2\end{array}$ & $\begin{array}{c}0.4 \\
9\end{array}$ & $\begin{array}{c}0.7 \\
5\end{array}$ & $\begin{array}{c}0.7 \\
9\end{array}$ & 0.76 & $\begin{array}{l}\text { SDG3 } \\
\mathrm{t}=-19.7 \\
2 \\
\mathrm{p}=0.00\end{array}$ \\
\hline
\end{tabular}

The highest mean score (highest level of compatibility) for SDG16 as a goal compared to the SDG3 targets was for SDG3 Target D at $1.58 \pm 0.79$. On the other hand, comparing SDG3 as a goal to the targets of SDG 16, SDG16 Target 6 scored $1.92 \pm 0.49$ which was the highest and therefore the most compatible SDG16 targets with SDG3. When the one sample t-test was computed with a test value of +3 , the SDG16 had a mean significantly differed from the test value $(\mathrm{t}=13.96, \mathrm{p}=0.00)$ and a similar result was obtained for SDG3 which had a significant difference from the test value $(\mathrm{t}=19.72, \mathrm{p}=0.00)$.

Table 7: Showing the Compatibility Scores of SDG16 Targets with SDG4 Targets

\begin{tabular}{|c|c|c|c|c|c|c|c|c|c|c|c|c|}
\hline \multirow{2}{*}{$\begin{array}{c}\text { SDG16 } \\
\text { TARGETS }\end{array}$} & \multicolumn{10}{|c|}{ SDG4 TARGETS } & \multirow{2}{*}{$\begin{array}{l}\text { MEAN } \\
\text { SCORE }\end{array}$} & \multirow{2}{*}{ SD } \\
\hline & T4.1 & T4.2 & T4.3 & T4.4 & T4.5 & T4.6 & T4.7 & T4.A & T4.B & T4.C & & \\
\hline T16.1 & 0 & 0 & 0 & 1 & 1 & 0 & 3 & 3 & 0 & 0 & 0.80 & 1.23 \\
\hline T16.2 & 1 & 1 & 0 & 2 & 1 & 0 & 3 & 3 & 0 & 0 & 1.10 & 1.20 \\
\hline T16.3 & 2 & 2 & 2 & 2 & 2 & 2 & 3 & 3 & 0 & 0 & 1.80 & 1.03 \\
\hline T16.4 & 0 & 0 & 0 & 1 & 1 & 1 & 3 & 3 & 0 & 1 & 1.00 & 1.15 \\
\hline T16.5 & 0 & 0 & 0 & 1 & 1 & 1 & 3 & 1 & 0 & 2 & 0.90 & 0.99 \\
\hline T16.6 & 2 & 2 & 2 & 2 & 2 & 2 & 3 & 2 & 2 & 2 & 2.10 & 0.32 \\
\hline T16.7 & 0 & 0 & 2 & 2 & 2 & 3 & 3 & 1 & 1 & 2 & 1.60 & 1.07 \\
\hline T16.8 & 0 & 0 & 1 & 2 & 2 & 2 & 3 & 1 & 3 & 3 & 1.70 & 1.16 \\
\hline T16.9 & 0 & 0 & 0 & 1 & 2 & 1 & 1 & 0 & 0 & 0 & 0.50 & 0.71 \\
\hline T16.10 & 2 & 2 & 2 & 2 & 2 & 3 & 3 & 1 & 2 & 2 & 2.10 & 0.57 \\
\hline T16.A & 1 & 1 & 1 & 2 & 1 & 1 & 2 & 1 & 2 & 2 & 1.40 & 0.52 \\
\hline T16.B & 2 & 2 & 2 & 2 & 2 & 2 & 2 & 2 & 2 & 2 & 2.00 & 0.00 \\
\hline MEAN & 0.83 & 0.83 & 1.00 & 1.67 & 1.58 & 1.50 & 2.67 & 1.75 & 1.00 & 1.33 & 1.42 & $\begin{array}{r}\text { SDG16 } \\
\mathrm{t}=-10.02 \\
\mathrm{p}=0.00\end{array}$ \\
\hline SD & 0.94 & 0.94 & 0.95 & 0.49 & 0.51 & 1.00 & 0.65 & 1.06 & 1.13 & 1.07 & 1.02 & $\begin{array}{c}\text { SDG4 } \\
\mathrm{t}=-8.94 \\
\mathrm{p}=0.00\end{array}$ \\
\hline
\end{tabular}


The highest mean score (highest level of compatibility) for SDG16 as a goal compared to the SDG4 targets was for SDG4 Target 7 at $2.67 \pm 0.65$. On the other hand, comparing SDG4 as a goal to the targets of SDG16, SDG16 Targets 6 and 10 scored $2.10 \pm 0.32$ and $2.10 \pm 0.57$ respectively which were the highest and therefore the most compatible SDG16 targets with SDG4. When the one sample t-test was computed with a test value of +3 , the SDG16 had a mean significantly differed from the test value $(\mathrm{t}=-10.02, \mathrm{p}=0.00)$ and a similar result was obtained for SDG4 which had a significant difference from the test value $(\mathrm{t}=-9.94, \mathrm{p}=0.00)$.

Table 8: Showing the Compatibility Scores of SDG16 Targets with SDG5 Targets

\begin{tabular}{|c|c|c|c|c|c|c|c|c|c|c|c|}
\hline \multirow{2}{*}{$\begin{array}{c}\text { SDG16 } \\
\text { TARGETS } \\
\end{array}$} & \multicolumn{9}{|c|}{ SDG 5 TARGETS } & \multirow{2}{*}{$\begin{array}{l}\text { MEAN } \\
\text { SCORE }\end{array}$} & \multirow{2}{*}{ SD } \\
\hline & T5.1 & T5.2 & T5.3 & T5.4 & T5.5 & T5.6 & T5.A & T5.B & T5.C & & \\
\hline T16.1 & 1 & 3 & 3 & 1 & 1 & 1 & 1 & 1 & 2 & 1.56 & 0.88 \\
\hline T16.2 & 0 & 3 & 3 & 1 & 0 & 2 & 1 & 1 & 2 & 1.44 & 1.13 \\
\hline T16.3 & 2 & 3 & 3 & 2 & 3 & 2 & 2 & 2 & 2 & 2.33 & 0.50 \\
\hline T16.4 & 0 & 2 & 3 & 1 & 1 & 1 & 1 & 2 & 2 & 1.44 & 0.88 \\
\hline T16.5 & 0 & 0 & 0 & 0 & 0 & 0 & 1 & 1 & 0 & 0.22 & 0.44 \\
\hline T16.6 & 1 & 3 & 3 & 1 & 2 & 2 & 2 & 3 & 2 & 2.11 & 0.78 \\
\hline T16.7 & 2 & 1 & 2 & 1 & 3 & 2 & 3 & 3 & 2 & 2.11 & 0.78 \\
\hline T16.8 & 2 & 2 & 2 & 1 & 3 & 3 & 3 & 2 & 3 & 2.33 & 0.71 \\
\hline T16.9 & 0 & 0 & 0 & 0 & 0 & 0 & 0 & 0 & 0 & 0.00 & 0.00 \\
\hline T16.10 & 2 & 3 & 2 & 1 & 3 & 3 & 3 & 3 & 3 & 2.56 & 0.73 \\
\hline T16.A & 1 & 2 & 2 & 1 & 1 & 2 & 2 & 2 & 2 & 1.67 & 0.50 \\
\hline T16.B & 3 & 3 & 3 & 2 & 2 & 3 & 3 & 3 & 3 & 2.78 & 0.44 \\
\hline MEAN & 1.17 & 2.08 & 2.17 & 1.00 & 1.58 & 1.75 & 1.83 & 1.92 & 1.92 & 1.71 & $\begin{array}{c}\text { SDG16 } \\
\mathrm{t}=-5.14 \\
\mathrm{p}=0.00\end{array}$ \\
\hline SD & 1.03 & 1.16 & 1.11 & 0.60 & 1.24 & 1.06 & 1.03 & 1.00 & 1.00 & 1.07 & $\begin{array}{l}\text { SDG5 } \\
\mathrm{t}=-9.71 \\
\mathrm{p}=0.00\end{array}$ \\
\hline
\end{tabular}

The highest mean score (highest level of compatibility) for SDG16 as a goal compared to the SDG5 targets was for SDG5 Target 3 at 2.17 \pm 1.11 . On the other hand, comparing SDG5 as a goal to the targets of SDG16, SDG16 Target B scored 2.78 \pm 0.44 which was the highest and therefore the most compatible SDG16 targets with SDG5. When the one sample t-test was computed with a test value of +3 , the SDG16 had a mean significantly differed from the test value $(t=-5.14, p=0.00)$ and a similar result was obtained for SDG5 which had a significant difference from the test value $(\mathrm{t}=-9.71, \mathrm{p}=0.00)$.

Table 9: Showing the Compatibility Scores of SDG16 Targets with SDG6 Targets

\begin{tabular}{|c|c|c|c|c|c|c|c|c|c|c|}
\hline \multirow{2}{*}{$\begin{array}{c}\text { SDG16 } \\
\text { TARGETS }\end{array}$} & \multicolumn{8}{|c|}{ SDG 6 TARGETS } & \multirow{2}{*}{$\begin{array}{l}\text { MEAN } \\
\text { SCORE }\end{array}$} & \multirow{2}{*}{ SD } \\
\hline & T6.1 & T6.2 & T6.3 & T6.4 & T6.5 & T6.6 & T6.A & T6.B & & \\
\hline T16.1 & 0 & 1 & 2 & 1 & 1 & 2 & 1 & 1 & 1.13 & 0.64 \\
\hline T16.2 & 0 & 0 & 0 & 0 & 0 & 0 & 0 & 0 & 0.00 & 0.00 \\
\hline T16.3 & 0 & 1 & 2 & 2 & 2 & 2 & 2 & 2 & 1.63 & 0.74 \\
\hline T16.4 & 0 & 0 & 0 & 0 & 0 & 1 & 1 & 1 & 0.38 & 0.52 \\
\hline T16.5 & 0 & 0 & 0 & 0 & 0 & 1 & 1 & 1 & 0.38 & 0.52 \\
\hline T16.6 & 1 & 1 & 2 & 2 & 2 & 2 & 2 & 2 & 1.75 & 0.46 \\
\hline T16.7 & 0 & 1 & 1 & 2 & 2 & 2 & 2 & 2 & 1.50 & 0.76 \\
\hline T16.8 & 1 & 1 & 2 & 2 & 2 & 2 & 2 & 2 & 1.75 & 0.46 \\
\hline T16.9 & 0 & 0 & 0 & 0 & 0 & 0 & 0 & 0 & 0.00 & 0.00 \\
\hline T16.10 & 1 & 1 & 1 & 2 & 2 & 2 & 1 & 1 & 1.38 & 0.52 \\
\hline T16.A & 1 & 1 & 1 & 1 & 1 & 1 & 2 & 1 & 1.13 & 0.35 \\
\hline T16.B & 0 & 2 & 2 & 2 & 2 & 2 & 3 & 2 & 1.90 & 0.83 \\
\hline MEAN & 0.33 & 0.75 & 1.08 & 1.17 & 1.17 & 1.42 & 1.42 & 1.25 & 1.07 & $\begin{array}{l}\text { SDG16 } \\
\mathrm{t}=-9.46 \\
\mathrm{p}=0.00\end{array}$ \\
\hline SD & 0.49 & 0.62 & 0.90 & 0.94 & 0.94 & 0.79 & 0.90 & 0.75 & 0.85 & $\begin{array}{l}\text { SDG6 } \\
\mathrm{t}=-14.81 \\
\mathrm{p}=0.00\end{array}$ \\
\hline
\end{tabular}

The highest mean score (highest level of compatibility) for SDG16 as a goal compared to the SDG6 targets were 
for SDG6 Targets 6 and A at $1.42 \pm 0.79$ and $1.42 \pm 0.90$ respectively. On the other hand, comparing SDG6 as a goal to the targets of SDG16, SDG16 Target B scored 1.90 \pm 0.83 which was the highest and therefore the most compatible SDG16 target with SDG6. When the one sample t-test was computed with a test value of +3 , the SDG16 had a mean significantly differed from the test value $(\mathrm{t}=-9.46, \mathrm{p}=0.00)$ and a similar result was obtained for SDG6 which had a significant difference from the test value $(\mathrm{t}=-14.81, \mathrm{p}=0.00)$.

Table 10: Showing the Compatibility Scores of SDG16 Targets with SDG7 Targets

\begin{tabular}{|c|c|c|c|c|c|c|c|}
\hline \multirow[b]{2}{*}{ SDG16 TARGETS } & \multicolumn{5}{|c|}{ SDG 7 TARGETS } & \multirow{2}{*}{$\begin{array}{r}\text { MEAN } \\
\text { SCORE }\end{array}$} & \multirow{2}{*}{ SD } \\
\hline & T7.1 & T7.2 & T7.3 & T7.A & T7.B & & \\
\hline T16.1 & 0 & 0 & 0 & 0 & 0 & 0.00 & 0.00 \\
\hline T16.2 & 0 & 0 & 0 & 0 & 0 & 0.00 & 0.00 \\
\hline T16.3 & 1 & 0 & 1 & 2 & 1 & 1.00 & 0.71 \\
\hline T16.4 & 0 & 0 & 0 & 0 & 0 & 0.00 & 0.00 \\
\hline T16.5 & 1 & 0 & 0 & 1 & 1 & 0.60 & 0.55 \\
\hline T16.6 & 2 & 1 & 1 & 2 & 2 & 1.60 & 0.55 \\
\hline T16.7 & 1 & 1 & 1 & 1 & 1 & 1.00 & 0.00 \\
\hline T16.8 & 2 & 2 & 1 & 2 & 2 & 1.80 & 0.45 \\
\hline T16.9 & 1 & 1 & 0 & 0 & 0 & 0.40 & 0.55 \\
\hline T16.10 & 1 & 2 & 1 & 3 & 2 & 1.80 & 0.84 \\
\hline T16.A & 1 & 1 & 1 & 2 & 1 & 1.20 & 0.45 \\
\hline T16.B & 1 & 2 & 2 & 2 & 2 & 1.80 & 0.45 \\
\hline MEAN & 0.92 & 0.83 & 0.67 & 1.25 & 1.00 & 4.67 & $\begin{array}{l}\text { SDG16 } \\
t=-9.87 \\
p=0.00\end{array}$ \\
\hline SD & 0.67 & 0.83 & 0.65 & 1.06 & 0.85 & 0.82 & $\begin{array}{l}\text { SDG7 } \\
t=-21.49 \\
p=0.00\end{array}$ \\
\hline
\end{tabular}

The highest mean score (highest level of compatibility) for SDG16 as a goal compared to the SDG7 targets was for SDG7 Targets A at 1.25 \pm 1.06 . On the other hand, comparing SDG7 as a goal to the targets of SDG16, SDG16 Targets 6,10 and B scored $1.80 \pm 0.45,1.80 \pm 0.84$ and $1.80 \pm 0.45$ respectively. This score was the highest and therefore the most compatible SDG16 targets with SDG7. When the one sample t-test was computed with a test value of +3 , the SDG16 had a mean significantly differed from the test value $(\mathrm{t}=-9.87, \mathrm{p}=0.00)$ and a similar result was obtained for SDG7 which had a significant difference from the test value $(\mathrm{t}=-21.49, \mathrm{p}=0.00)$.

Table 11: Showing the Compatibility Scores of SDG16 Targets with SDG8 Targets

\begin{tabular}{|c|c|c|c|c|c|c|c|c|c|c|c|c|c|c|}
\hline \multirow{2}{*}{$\begin{array}{c}\text { SDG16 } \\
\text { TARGET } \\
\mathrm{S}\end{array}$} & \multicolumn{12}{|c|}{ SDG 8 TARGETS } & \multirow{2}{*}{$\begin{array}{c}\text { MEAN } \\
\text { SCOR } \\
\text { E }\end{array}$} & \multirow[b]{2}{*}{ SD } \\
\hline & $\begin{array}{c}\text { T8. } \\
1\end{array}$ & $\begin{array}{c}\text { T8. } \\
2\end{array}$ & $\begin{array}{c}\text { T8. } \\
3\end{array}$ & $\begin{array}{c}\text { T8. } \\
4\end{array}$ & $\begin{array}{c}\text { T8. } \\
5\end{array}$ & $\begin{array}{c}\text { T8. } \\
6\end{array}$ & $\begin{array}{c}\text { T8. } \\
7\end{array}$ & $\begin{array}{c}\text { T8. } \\
8\end{array}$ & $\begin{array}{c}\text { T8. } \\
9\end{array}$ & $\begin{array}{c}\text { T8.1 } \\
\text { 0 }\end{array}$ & $\begin{array}{c}\text { T8. } \\
\text { A }\end{array}$ & $\begin{array}{c}\text { T8. } \\
\text { B }\end{array}$ & & \\
\hline T16.1 & 0 & 0 & 0 & 0 & 0 & 1 & 2 & 1 & 0 & 0 & 0 & 1 & 0.42 & 0.67 \\
\hline T16.2 & 0 & 0 & 0 & 0 & 1 & 0 & 3 & 0 & 0 & 0 & 0 & 2 & 0.50 & 1.00 \\
\hline T16.3 & 0 & 1 & 2 & 2 & 2 & 2 & 2 & 2 & 2 & 2 & 3 & 2 & 1.83 & 0.72 \\
\hline T16.4 & 0 & 0 & 0 & 0 & 0 & 0 & 1 & 2 & 0 & 3 & 1 & 1 & 0.67 & 0.98 \\
\hline T16.5 & 1 & 1 & 1 & 0 & 1 & 0 & 1 & 0 & 0 & 3 & 0 & 1 & 0.75 & 0.87 \\
\hline T16.6 & 1 & 2 & 2 & 2 & 2 & 2 & 2 & 2 & 1 & 3 & 2 & 2 & 1.92 & 0.51 \\
\hline T16.7 & 0 & 2 & 2 & 2 & 2 & 1 & 1 & 2 & 1 & 2 & 1 & 1 & 1.42 & 0.67 \\
\hline T16.8 & 2 & 2 & 2 & 2 & 2 & 2 & 2 & 2 & 2 & 2 & 3 & 3 & 2.17 & 0.39 \\
\hline T16.9 & 0 & 0 & 0 & 1 & 0 & 0 & 1 & 0 & 0 & 1 & 0 & 0 & 0.25 & 0.45 \\
\hline T16.10 & 1 & 2 & 2 & 2 & 2 & 2 & 1 & 2 & 1 & 2 & 1 & 2 & 1.67 & 0.49 \\
\hline T16.A & 1 & 1 & 1 & 2 & 1 & 1 & 2 & 2 & 2 & 2 & 2 & 2 & 1.58 & 0.51 \\
\hline T16.B & 0 & 1 & 2 & 1 & 2 & 2 & 2 & 2 & 3 & 2 & 2 & 2 & 1.75 & 0.75 \\
\hline MEAN & 0.50 & 1.00 & 1.17 & 1.17 & 1.25 & 1.08 & 1.67 & 1.42 & 1.00 & 1.83 & 1.25 & 1.58 & 1.24 & $\begin{array}{c}\text { SDG16 } \\
t=-8.99 \\
p=0.00\end{array}$ \\
\hline SD & 0.67 & 0.85 & 0.94 & 0.94 & 0.87 & 0.90 & 0.65 & 0.90 & 1.04 & 1.03 & 1.14 & 0.79 & 0.93 & $\begin{array}{l}\text { SDG8 } \\
t=-17.1 \\
9 \\
p=0.00\end{array}$ \\
\hline
\end{tabular}


The highest mean score (highest level of compatibility) for SDG16 as a goal compared to the SDG8 targets was for SDG8 Targets 10 at $1.83 \pm 1.03$. On the other hand, comparing SDG8 as a goal to the targets of SDG16, SDG16 Target 8 scored 2.17 \pm 0.39 which were the highest and therefore the most compatible SDG16 targets with SDG8. When the one sample t-test was computed with a test value of +3 , the SDG16 had a mean significantly differed from the test value $(\mathrm{t}=-8.99, \mathrm{p}=0.00)$ and a similar result was obtained for SDG8 which had a significant difference from the test value $(\mathrm{t}=-17.19, \mathrm{p}=0.00)$.

Table 12: Showing the Compatibility Scores of SDG16 Targets with SDG9 Targets

\begin{tabular}{|c|c|c|c|c|c|c|c|c|c|c|}
\hline \multirow{2}{*}{$\begin{array}{c}\text { SDG16 } \\
\text { TARGETS }\end{array}$} & \multicolumn{8}{|c|}{ SDG 9 TARGETS } & \multirow{2}{*}{$\begin{array}{l}\text { MEAN } \\
\text { SCORE }\end{array}$} & \multirow{2}{*}{ SD } \\
\hline & T9.1 & T9.2 & T9.3 & T9.4 & T9.5 & T9.A & T9.B & T9.C & & \\
\hline T16.1 & 0 & 0 & 0 & 0 & 1 & 2 & 0 & 1 & 0.50 & 0.76 \\
\hline T16.2 & 0 & 0 & 0 & 0 & 1 & 0 & 0 & 1 & 0.25 & 0.46 \\
\hline T16.3 & 1 & 2 & 3 & 1 & 2 & 2 & 1 & 2 & 1.75 & 0.71 \\
\hline T16.4 & 0 & 0 & 0 & 0 & 1 & 0 & 0 & 1 & 0.25 & 0.46 \\
\hline T16.5 & 0 & 0 & 0 & 0 & 1 & 0 & 0 & 1 & 0.25 & 0.46 \\
\hline T16.6 & 1 & 2 & 2 & 1 & 2 & 2 & 1 & 2 & 1.63 & 0.52 \\
\hline T16.7 & 1 & 1 & 2 & 1 & 1 & 2 & 1 & 1 & 1.25 & 0.46 \\
\hline T16.8 & 2 & 2 & 2 & 2 & 2 & 2 & 2 & 2 & 2.00 & 0.00 \\
\hline T16.9 & 0 & 0 & 0 & 0 & 0 & 0 & 0 & 1 & 0.13 & 0.35 \\
\hline T16.10 & 2 & 1 & 2 & 2 & 1 & 1 & 2 & 3 & 1.75 & 0.71 \\
\hline T16.A & 1 & 1 & 1 & 1 & 1 & 2 & 1 & 1 & 1.13 & 0.35 \\
\hline T16.B & 1 & 2 & 2 & 2 & 1 & 2 & 2 & 2 & 1.75 & 0.46 \\
\hline MEAN & 0.75 & 0.92 & 1.17 & 0.83 & 1.17 & 1.25 & 0.83 & 1.50 & 1.05 & $\begin{array}{c}\text { SDG16 } \\
\mathrm{t}=-9.27 \\
\mathrm{p}=0.00\end{array}$ \\
\hline SD & 0.75 & 0.90 & 1.11 & 0.83 & 0.58 & 0.97 & 0.83 & 0.67 & 0.85 & $\begin{array}{l}\text { SDG9 } \\
\mathrm{t}=-21.15 \\
\mathrm{p}=0.00\end{array}$ \\
\hline
\end{tabular}

The highest mean score (highest level of compatibility) for SDG16 as a goal compared to the SDG9 targets was for SDG9 Target $C$ at $1.50 \pm 0.67$. On the other hand, comparing SDG9 as a goal to the targets of SDG16, SDG16 Target 8 scored 2.00 \pm 0.00 which were the highest and therefore the most compatible SDG16 targets with SDG9. When the one sample t-test was computed with a test value of +3 , the SDG16 had a mean significantly differed from the test value $(t=-9.27, p=0.00)$ and a similar result was obtained for SDG9 which had a significant difference from the test value $(\mathrm{t}=-21.15, \mathrm{p}=0.00)$.

Table 13: Showing the Compatibility Scores of SDG16 Targets with SDG10 Targets

\begin{tabular}{|c|c|c|c|c|c|c|c|c|c|c|c|c|}
\hline \multirow{2}{*}{$\begin{array}{c}\text { SDG16 } \\
\text { TARGET } \\
\text { S }\end{array}$} & \multicolumn{10}{|c|}{ SDG 10 TARGETS } & \multirow{2}{*}{$\begin{array}{c}\text { MEAN } \\
\text { SCOR } \\
\text { E }\end{array}$} & \multirow[b]{2}{*}{ SD } \\
\hline & $\begin{array}{c}\text { T10. } \\
1\end{array}$ & $\begin{array}{c}\text { T10. } \\
2\end{array}$ & $\begin{array}{c}\text { T10. } \\
3\end{array}$ & $\begin{array}{c}\text { T10. } \\
4\end{array}$ & $\begin{array}{c}\text { T10. } \\
5\end{array}$ & $\begin{array}{c}\text { T10. } \\
6\end{array}$ & $\begin{array}{c}\text { T10. } \\
7\end{array}$ & $\begin{array}{c}\text { T10. } \\
\text { A }\end{array}$ & $\begin{array}{c}\text { T10. } \\
\text { B }\end{array}$ & $\begin{array}{c}\text { T10. } \\
\text { C }\end{array}$ & & \\
\hline T16.1 & 1 & 2 & 3 & 2 & 0 & 1 & 2 & 0 & 1 & 0 & 1.20 & 1.03 \\
\hline T16.2 & 1 & 2 & 3 & 2 & 0 & 1 & 3 & 0 & 0 & 0 & 1.20 & 1.23 \\
\hline T16.3 & 2 & 3 & 3 & 3 & 2 & 2 & 2 & 0 & 1 & 0 & 1.80 & 1.14 \\
\hline T16.4 & 0 & 0 & 0 & 0 & 2 & 1 & 1 & 0 & 2 & 0 & 0.60 & 0.84 \\
\hline T16.5 & 0 & 1 & 2 & 1 & 1 & 1 & 0 & 0 & 1 & 0 & 0.70 & 0.67 \\
\hline T16.6 & 2 & 3 & 3 & 3 & 2 & 2 & 2 & 0 & 2 & 1 & 2.00 & 0.94 \\
\hline T16.7 & 2 & 1 & 3 & 3 & 1 & 2 & 0 & 0 & 1 & 0 & 1.30 & 1.16 \\
\hline T16.8 & 1 & 2 & 2 & 2 & 3 & 3 & 1 & 3 & 2 & 1 & 2.00 & 0.82 \\
\hline T16.9 & 1 & 1 & 2 & 1 & 1 & 1 & 3 & 0 & 0 & 0 & 1.00 & 0.94 \\
\hline T16.10 & 2 & 3 & 2 & 2 & 2 & 1 & 2 & 3 & 1 & 1 & 1.90 & 0.74 \\
\hline T16.A & 1 & 2 & 1 & 2 & 2 & 2 & 2 & 3 & 2 & 1 & 1.80 & 0.63 \\
\hline T16.B & 2 & 3 & 3 & 2 & 2 & 1 & 2 & 1 & 1 & 1 & 1.80 & 0.79 \\
\hline MEAN & 1.25 & 1.92 & 2.25 & 1.92 & 1.50 & 1.50 & 1.67 & 0.83 & 1.17 & 0.42 & 1.73 & $\begin{array}{l}\text { SDG16 } \\
\mathrm{t}=-10.6 \\
8 \\
\mathrm{p}=0.00\end{array}$ \\
\hline SD & 0.75 & 1.00 & 0.97 & 0.90 & 0.90 & 0.67 & 0.98 & 1.34 & 0.72 & 0.51 & 1.01 & $\begin{array}{c}\text { SDG10 } \\
\mathrm{t}=-8.99 \\
\mathrm{p}=0.00\end{array}$ \\
\hline
\end{tabular}


The highest mean score (highest level of compatibility) for SDG16 as a goal compared to the SDG10 targets was for SDG10 Target 3 at $2.25 \pm 0.97$. On the other hand, comparing SDG10 as a goal to the targets of SDG16 showed that SDG16 Targets 6 and 8 scored $2.00 \pm 0.94$ and 2.00 \pm 0.82 which were the highest and therefore the most compatible SDG16 targets with SDG10. When the one sample t-test was computed with a test value of +3 , the SDG16 had a mean significantly differed from the test value $(t=-10.68, p=0.00)$ and a similar result was obtained for SDG10 which had a significant difference from the test value $(t=-8.99, \mathrm{p}=0.00)$.

Table 14: Showing the Compatibility Scores of SDG16 Targets with SDG11 Targets

\begin{tabular}{|c|c|c|c|c|c|c|c|c|c|c|c|c|}
\hline SDG16 & \multicolumn{10}{|c|}{ SDG 11 TARGETS } & \multirow{2}{*}{$\begin{array}{l}\text { MEAN } \\
\text { SCORE }\end{array}$} & \multirow{2}{*}{ SD } \\
\hline TARGETS & T11.1 & T11.2 & T11.3 & T11.4 & T11.5 & T11.6 & T11.7 & T11.A & T11.B & T11.C & & \\
\hline T16.1 & 1 & 2 & 2 & 3 & 3 & 1 & 0 & 0 & 0 & 0 & 1.20 & 1.23 \\
\hline T16.2 & 0 & 0 & 2 & 0 & 1 & 0 & 0 & 0 & 1 & 0 & 0.40 & 0.70 \\
\hline T16.3 & 2 & 1 & 2 & 1 & 2 & 2 & 1 & 0 & 1 & 1 & 1.30 & 0.67 \\
\hline T16.4 & 0 & 0 & 1 & 0 & 1 & 0 & 0 & 0 & 0 & 0 & 0.20 & 0.42 \\
\hline T16.5 & 0 & 0 & 0 & 0 & 0 & 0 & 0 & 0 & 0 & 0 & 0.00 & 0.00 \\
\hline T16.6 & 1 & 1 & 1 & 0 & 1 & 1 & 0 & 1 & 2 & 1 & 0.90 & 0.57 \\
\hline T16.7 & 1 & 0 & 1 & 1 & 0 & 0 & 0 & 1 & 2 & 1 & 0.70 & 0.67 \\
\hline T16.8 & 2 & 1 & 2 & 2 & 2 & 2 & 0 & 0 & 1 & 2 & 1.40 & 0.84 \\
\hline T16.9 & 1 & 0 & 1 & 1 & 1 & 0 & 0 & 0 & 1 & 0 & 0.50 & 0.53 \\
\hline T16.10 & 2 & 1 & 2 & 3 & 2 & 2 & 1 & 1 & 1 & 1 & 1.60 & 0.70 \\
\hline T16.A & 1 & 1 & 2 & 2 & 1 & 1 & 0 & 1 & 1 & 2 & 1.20 & 0.63 \\
\hline T16.B & 2 & 1 & 1 & 2 & 1 & 2 & 1 & 2 & 1 & 1 & 1.40 & 0.52 \\
\hline MEAN & 1.08 & 0.67 & 1.42 & 1.25 & 1.25 & 0.92 & 0.25 & 0.50 & 0.92 & 0.75 & 0.90 & $\begin{array}{c}\text { SDG16 } \\
\mathrm{t}=-13.75 \\
\mathrm{p}=0.00\end{array}$ \\
\hline SD & 0.79 & 0.65 & 0.67 & 1.14 & 0.87 & 0.90 & 0.45 & 0.67 & 0.67 & 0.75 & 0.82 & $\begin{array}{c}\text { SDG11 } \\
t=-18.13 \\
p=0.00\end{array}$ \\
\hline
\end{tabular}

The highest mean score (highest level of compatibility) for SDG16 as a goal compared to the SDG11 targets was for SDG11 Target 3 at $1.42 \pm 0.67$. On the other hand, comparing SDG11 as a goal to the targets of SDG16, SDG16 Target 10 scored 1.60 \pm 0.70 , which was the highest and therefore the most compatible SDG16 target with SDG11. When the one sample t-test was computed with a test value of +3 , the SDG16 had a mean significantly differed from the test value $(\mathrm{t}=-13.75, \mathrm{p}=0.00)$ and a similar result was obtained for SDG11 which had a significant difference from the test value $(\mathrm{t}=-18.13, \mathrm{p}=0.00)$.

Table 15: Showing the Compatibility Scores of SDG16 Targets with SDG12 Targets

\begin{tabular}{|c|c|c|c|c|c|c|c|c|c|c|c|c|c|}
\hline \multirow{2}{*}{$\begin{array}{c}\text { SDG16 } \\
\text { TARGET } \\
\text { S }\end{array}$} & \multicolumn{11}{|c|}{ SDG 12 TARGETS } & \multirow{2}{*}{$\begin{array}{c}\text { MEAN } \\
\text { SCOR } \\
\text { E }\end{array}$} & \multirow[b]{2}{*}{ SD } \\
\hline & $\begin{array}{c}\text { T12. } \\
1\end{array}$ & $\begin{array}{c}\text { T12. } \\
2\end{array}$ & $\begin{array}{c}\text { T12. } \\
3\end{array}$ & $\begin{array}{c}\text { T12. } \\
4\end{array}$ & $\begin{array}{c}\text { T12. } \\
5\end{array}$ & $\begin{array}{c}\text { T12. } \\
6\end{array}$ & $\begin{array}{c}\text { T12. } \\
7\end{array}$ & $\begin{array}{c}\text { T12. } \\
8\end{array}$ & $\begin{array}{c}\text { T12. } \\
\text { A }\end{array}$ & $\begin{array}{c}\text { T12. } \\
\text { B }\end{array}$ & $\begin{array}{c}\text { T12. } \\
\text { C }\end{array}$ & & \\
\hline T16.1 & 0 & 0 & 0 & 1 & 0 & 0 & 0 & 2 & 0 & 3 & 0 & 0.55 & 1.04 \\
\hline T16.2 & 0 & 0 & 0 & 0 & 0 & 0 & 0 & 2 & 0 & 3 & 0 & 0.45 & 1.04 \\
\hline T16.3 & 1 & 1 & 1 & 1 & 1 & 1 & 2 & 2 & 1 & 2 & 1 & 1.27 & 0.47 \\
\hline T16.4 & 0 & 0 & 0 & 0 & 0 & 0 & 1 & 2 & 1 & 2 & 0 & 0.55 & 0.82 \\
\hline T16.5 & 0 & 0 & 0 & 0 & 0 & 1 & 3 & 2 & 0 & 2 & 1 & 0.82 & 1.08 \\
\hline T16.6 & 1 & 1 & 1 & 1 & 1 & 1 & 3 & 2 & 1 & 2 & 2 & 1.45 & 0.69 \\
\hline T16.7 & 1 & 1 & 1 & 1 & 1 & 1 & 1 & 2 & 0 & 2 & 1 & 1.09 & 0.54 \\
\hline T16.8 & 2 & 2 & 2 & 2 & 2 & 2 & 2 & 2 & 1 & 2 & 2 & 1.91 & 0.30 \\
\hline T16.9 & 0 & 0 & 0 & 0 & 0 & 0 & 0 & 1 & 1 & 0 & 0 & 0.18 & 0.40 \\
\hline T16.10 & 1 & 1 & 1 & 1 & 1 & 1 & 1 & 3 & 1 & 2 & 2 & 1.36 & 0.67 \\
\hline T16.A & 0 & 0 & 0 & 1 & 1 & 1 & 1 & 2 & 1 & 2 & 1 & 0.91 & 0.70 \\
\hline T16.B & 1 & 1 & 1 & 1 & 1 & 1 & 1 & 2 & 1 & 2 & 0 & 1.09 & 0.54 \\
\hline MEAN & 0.58 & 0.58 & 0.58 & 0.75 & 0.67 & 0.75 & 1.25 & 2.00 & 0.67 & 2.00 & 0.83 & 0.97 & $\begin{array}{l}\text { SDG16 } \\
\mathrm{t}=-14.3 \\
1 \\
\mathrm{p}=0.00\end{array}$ \\
\hline SD & 0.67 & 0.67 & 0.67 & 0.62 & 0.65 & 0.62 & 1.06 & 0.43 & 0.49 & 0.74 & 0.83 & 0.85 & $\begin{array}{l}\text { SDG12 } \\
\mathrm{t}=-12.4 \\
0 \\
\mathrm{p}=0.00\end{array}$ \\
\hline
\end{tabular}


The highest mean score (highest level of compatibility) for SDG16 as a goal compared to the SDG12 targets were for SDG12 Targets 8 and B at 2.00 \pm 0.43 . On the other hand, comparing SDG12 as a goal to the targets of SDG16, SDG16 Target 8 scored $1.91 \pm 0.30$ which was the highest and therefore the most compatible SDG16 targets with SDG12. When the one sample t-test was computed with a test value of +3 , the SDG16 had a mean significantly differed from the test value $(\mathrm{t}=-14.31, \mathrm{p}=0.00)$ and a similar result was obtained for SDG12 which had a significant difference from the test value $(\mathrm{t}=-12.40, \mathrm{p}=0.00)$.

Table 16: Showing the Compatibility Scores of SDG16 Targets with SDG13 Targets

\begin{tabular}{|c|c|c|c|c|c|c|c|}
\hline \multirow[b]{2}{*}{ SDG16 TARGETS } & \multicolumn{5}{|c|}{ SDG 13 TARGETS } & \multirow{2}{*}{$\begin{array}{c}\text { MEAN } \\
\text { SCORE }\end{array}$} & \multirow{2}{*}{ SD } \\
\hline & T13.1 & T13.2 & T13.3 & T31.A & T13.B & & \\
\hline T16.1 & 3 & 0 & 1 & 1 & 0 & 1.00 & 1.22 \\
\hline T16.2 & 0 & 0 & 0 & 0 & 0 & 0.00 & 0.00 \\
\hline T16.3 & 1 & 1 & 2 & 2 & 1 & 1.40 & 0.55 \\
\hline T16.4 & 0 & 0 & 0 & 0 & 0 & 0.00 & 0.00 \\
\hline T16.5 & 0 & 0 & 0 & 0 & 0 & 0.00 & 0.00 \\
\hline T16.6 & 1 & 1 & 1 & 1 & 1 & 1.00 & 0.00 \\
\hline T16.7 & 1 & 0 & 1 & 1 & 1 & 0.80 & 0.45 \\
\hline T16.8 & 2 & 1 & 2 & 2 & 2 & 1.80 & 0.45 \\
\hline T16.9 & 0 & 0 & 0 & 0 & 0 & 0.00 & 0.00 \\
\hline T16.10 & 2 & 1 & 1 & 3 & 3 & 2.00 & 1.00 \\
\hline T16.A & 2 & 1 & 0 & 0 & 2 & 1.00 & 1.00 \\
\hline T16.B & 1 & 1 & 0 & 0 & 2 & 0.80 & 0.84 \\
\hline MEAN & 1.08 & 0.50 & 0.67 & 0.83 & 1.00 & 0.82 & $\begin{array}{c}\text { SDG16 } \\
\mathrm{t}=-10.72 \\
\mathrm{p}=0.00\end{array}$ \\
\hline SD & 1.00 & 0.52 & 0.78 & 1.03 & 1.04 & 0.89 & $\begin{array}{c}\text { SDG13 } \\
\mathrm{t}=-20.59 \\
\mathrm{p}=0.00\end{array}$ \\
\hline
\end{tabular}

The highest mean score (highest level of compatibility) for SDG16 as a goal compared to the SDG13 targets was for SDG13 Target 1 at1.08 \pm 1.00 . On the other hand, comparing SDG13 as a goal to the targets of SDG16, SDG16 Target 10 scored 2.00 \pm 1.00 which was the highest and therefore the most compatible SDG16 targets with SDG10. When the one sample t-test was computed with a test value of +3 , the SDG16 had a mean significantly differed from the test value $(\mathrm{t}=-10.72, \mathrm{p}=0.00)$ and a similar result was obtained for SDG13 which had a significant difference from the test value $(\mathrm{t}=-20.59, \mathrm{p}=0.00)$.

Table 17: Showing the Compatibility Scores of SDG16 Targets with SDG14 Targets

\begin{tabular}{|c|c|c|c|c|c|c|c|c|c|c|c|c|}
\hline \multirow{2}{*}{$\begin{array}{c}\text { SDG16 } \\
\text { TARGET } \\
\mathbf{S}\end{array}$} & \multicolumn{10}{|c|}{ SDG 14 TARGETS } & \multirow{2}{*}{$\begin{array}{c}\text { MEAN } \\
\text { SCOR } \\
\text { E }\end{array}$} & \multirow[b]{2}{*}{ SD } \\
\hline & $\begin{array}{c}\text { T14. } \\
1\end{array}$ & $\begin{array}{c}\text { T14. } \\
2\end{array}$ & $\begin{array}{c}\text { T14. } \\
3\end{array}$ & $\begin{array}{c}\text { T14. } \\
4\end{array}$ & $\begin{array}{c}\text { T14. } \\
5\end{array}$ & $\begin{array}{c}\text { T14. } \\
6\end{array}$ & $\begin{array}{c}\text { T14. } \\
7\end{array}$ & $\begin{array}{c}\text { T14. } \\
\text { A }\end{array}$ & $\begin{array}{c}\text { T14. } \\
\text { B }\end{array}$ & $\begin{array}{c}\text { T14. } \\
\text { C }\end{array}$ & & \\
\hline T16.1 & 1 & 0 & 0 & 1 & 1 & 1 & 0 & 0 & 0 & 0 & 0.40 & 0.52 \\
\hline T16.2 & 0 & 0 & 0 & 0 & 0 & 0 & 0 & 0 & 0 & 0 & 0.00 & 0.00 \\
\hline T16.3 & 2 & 1 & 1 & 2 & 1 & 1 & 1 & 1 & 1 & 2 & 1.30 & 0.48 \\
\hline T16.4 & 0 & 0 & 0 & 0 & 0 & 0 & 0 & 0 & 0 & 0 & 0.00 & 0.00 \\
\hline T16.5 & 0 & 0 & 0 & 0 & 0 & 0 & 0 & 0 & 0 & 0 & 0.00 & 0.00 \\
\hline T16.6 & 1 & 1 & 1 & 1 & 1 & 1 & 1 & 1 & 1 & 1 & 1.00 & 0.00 \\
\hline T16.7 & 0 & 0 & 0 & 1 & 1 & 1 & 1 & 1 & 1 & 3 & 0.90 & 0.88 \\
\hline T16.8 & 1 & 1 & 1 & 1 & 1 & 1 & 3 & 2 & 1 & 3 & 1.50 & 0.85 \\
\hline T16.9 & 0 & 0 & 0 & 0 & 0 & 0 & 0 & 0 & 0 & 0 & 0.00 & 0.00 \\
\hline T16.10 & 2 & 0 & 1 & 1 & 1 & 1 & 1 & 2 & 1 & 2 & 1.20 & 0.63 \\
\hline T16.A & 1 & 1 & 1 & 1 & 1 & 1 & 1 & 2 & 1 & 2 & 1.20 & 0.42 \\
\hline T16.B & 0 & 0 & 0 & 0 & 0 & 0 & 0 & 0 & 0 & 0 & 0.00 & 0.00 \\
\hline MEAN & 0.67 & 0.33 & 0.42 & 0.67 & 0.58 & 0.58 & 0.67 & 0.75 & 0.50 & 1.08 & 0.63 & $\begin{array}{l}\text { SDG16 } \\
t=-13.4 \\
7 \\
p=0.00\end{array}$ \\
\hline SD & 0.78 & 0.49 & 0.51 & 0.65 & 0.51 & 0.51 & 0.89 & 0.87 & 0.52 & 1.24 & 0.73 & $\begin{array}{l}\text { SDG14 } \\
\mathrm{t}=-36.5 \\
7 \\
\mathrm{p}=0.00\end{array}$ \\
\hline
\end{tabular}


The highest mean score (highest level of compatibility) for SDG16 as a goal compared to the SDG14 targets was for SDG14 Target C at $1.08 \pm 1.24$. On the other hand, comparing SDG14 as a goal to the targets of SDG16, SDG16 Targets 8 scored $1.5 \pm 0.85$ which was the highest and therefore the most compatible SDG16 targets with SDG14. When the one sample t-test was computed with a test value of +3 , the SDG16 had a mean significantly differed from the test value $(\mathrm{t}=-13.47, \mathrm{p}=0.00)$ and a similar result was obtained for SDG14 which had a significant difference from the test value $(\mathrm{t}=-36.57, \mathrm{p}=0.00)$.

Table 18: Showing the Compatibility Scores of SDG16 Targets with SDG15 Targets

\begin{tabular}{|c|c|c|c|c|c|c|c|c|c|c|c|c|c|c|}
\hline \multirow{2}{*}{$\begin{array}{c}\text { SDG16 } \\
\text { TARGE } \\
\text { TS }\end{array}$} & \multicolumn{12}{|c|}{ SDG 15 TARGETS } & \multirow{2}{*}{$\begin{array}{c}\text { MEA } \\
\mathbf{N} \\
\text { SCOR } \\
\mathbf{E}\end{array}$} & \multirow[b]{2}{*}{ SD } \\
\hline & $\begin{array}{c}\text { T15. } \\
1\end{array}$ & $\begin{array}{c}\text { T15. } \\
2\end{array}$ & $\begin{array}{c}\text { T15. } \\
3\end{array}$ & $\begin{array}{c}\text { T15. } \\
4\end{array}$ & $\begin{array}{c}\text { T15. } \\
5\end{array}$ & $\begin{array}{c}\text { T15. } \\
6\end{array}$ & $\begin{array}{c}\text { T15. } \\
7\end{array}$ & $\begin{array}{c}\text { T15. } \\
8\end{array}$ & $\begin{array}{c}\text { T15. } \\
9\end{array}$ & $\begin{array}{c}\text { T15. } \\
\text { A }\end{array}$ & $\underset{\text { B }}{\text { T15. }}$ & $\underset{\text { C }}{\text { T15. }}$ & & \\
\hline T16.1 & 0 & 1 & 1 & 1 & 2 & 0 & 2 & 0 & 0 & 0 & 0 & 1 & 0.67 & 0.78 \\
\hline T16.2 & 0 & 0 & 0 & 0 & 0 & 0 & 0 & 0 & 0 & 0 & 0 & 0 & 0.00 & 0.00 \\
\hline T16.3 & 1 & 2 & 2 & 1 & 2 & 1 & 2 & 0 & 2 & 1 & 1 & 1 & 1.33 & 0.65 \\
\hline T16.4 & 0 & 0 & 0 & 0 & 0 & 0 & 0 & 0 & 0 & 0 & 0 & 0 & 0.00 & 0.00 \\
\hline T16.5 & 0 & 0 & 0 & 0 & 0 & 0 & 0 & 0 & 0 & 0 & 0 & 0 & 0.00 & 0.00 \\
\hline T16.6 & 2 & 2 & 1 & 1 & 2 & 1 & 1 & 1 & 1 & 1 & 1 & 1 & 1.25 & 0.45 \\
\hline T16.7 & 1 & 1 & 1 & 1 & 1 & 1 & 1 & 1 & 1 & 1 & 1 & 1 & 1.00 & 0.00 \\
\hline T16.8 & 3 & 2 & 1 & 1 & 2 & 2 & 2 & 2 & 1 & 2 & 3 & 3 & 2.00 & 0.74 \\
\hline T16.9 & 0 & 0 & 0 & 0 & 0 & 0 & 0 & 0 & 0 & 0 & 0 & 0 & 0.00 & 0.00 \\
\hline T16.10 & 1 & 1 & 1 & 1 & 2 & 2 & 2 & 0 & 1 & 2 & 2 & 3 & 1.50 & 0.80 \\
\hline T16.A & 0 & 1 & 1 & 0 & 1 & 0 & 0 & 0 & 0 & 1 & 0 & 1 & 0.42 & 0.51 \\
\hline T16.B & 0 & 1 & 0 & 0 & 0 & 0 & 0 & 0 & 2 & 0 & 0 & 0 & 0.25 & 0.62 \\
\hline MEAN & 0.67 & 0.92 & 0.67 & $\mathbf{0 . 5 0}$ & 1.00 & 0.58 & 0.83 & 0.33 & 0.67 & 0.67 & 0.67 & 0.92 & 0.70 & $\begin{array}{l}\text { SDG1 } \\
\mathbf{6} \\
\mathrm{t}=-11 . \\
40 \\
\mathrm{p}=0.0 \\
0\end{array}$ \\
\hline SD & 0.98 & 0.79 & 0.65 & 0.52 & 0.95 & 0.79 & 0.94 & 0.65 & 0.78 & 0.78 & 0.79 & 0.79 & 0.83 & $\begin{array}{l}\text { SDG1 } \\
\mathbf{5} \\
\mathrm{t}=-41 . \\
77 \\
\mathrm{p}=0.0 \\
0\end{array}$ \\
\hline
\end{tabular}

The highest mean score (highest level of compatibility) for SDG16 as a goal compared to the SDG15 targets was for SDG15 Target 5 at $1.00 \pm 0.95$. On the other hand, comparing SDG14 as a goal to the targets of SDG16, SDG16 Targets 8 scored 2.0 \pm 0.74 which was the highest and therefore the most compatible SDG16 targets with SDG15. When the one sample t-test was computed with a test value of +3 , the SDG16 had a mean significantly differed from the test value $(\mathrm{t}=-11.40, \mathrm{p}=0.00)$ and a similar result was obtained for SDG15 which had a significant difference from the test value $(\mathrm{t}=-41.77, \mathrm{p}=0.00)$. 
Table 19: Showing the Compatibility Scores of SDG16 Targets with SDG17 Targets

\begin{tabular}{|c|c|c|c|c|c|c|c|c|c|c|c|c|c|c|c|c|c|c|c|c|c|}
\hline SDG1 & \multicolumn{19}{|c|}{ SDG 17 TARGETS } & \multirow{2}{*}{$\begin{array}{c}\text { ME } \\
\text { AN } \\
\text { SCO } \\
\text { RE }\end{array}$} & \multirow[b]{2}{*}{ SD } \\
\hline $\begin{array}{c}6 \\
\text { TARG } \\
\text { ETS }\end{array}$ & 1 & 2 & 3 & 4 & 5 & 6 & 7 & 8 & 9 & 10 & 11 & 12 & 13 & 14 & 15 & 16 & 17 & 18 & 19 & & \\
\hline T16.1 & 1 & 1 & 1 & 1 & 1 & 1 & 1 & 0 & 1 & 0 & 0 & 0 & 0 & 0 & 0 & 0 & 0 & 0 & 0 & 0.42 & 0.51 \\
\hline T16.2 & 1 & 1 & 1 & 1 & 1 & 1 & 1 & 0 & 1 & 0 & 0 & 0 & 0 & 0 & 0 & 0 & 0 & 0 & 0 & 0.42 & 0.51 \\
\hline T16.3 & 2 & 1 & 1 & 1 & 2 & 2 & 2 & 1 & 1 & 1 & 1 & 0 & 0 & 3 & 3 & 3 & 0 & 0 & 0 & 1.26 & 1.05 \\
\hline T16.4 & 1 & 1 & 1 & 1 & 2 & 1 & 1 & 0 & 1 & 2 & 0 & 0 & 0 & 0 & 0 & 0 & 0 & 0 & 0 & 0.58 & 0.69 \\
\hline T16.5 & 1 & 1 & 1 & 1 & 2 & 2 & 1 & 1 & 1 & 2 & 0 & 0 & 1 & 0 & 0 & 0 & 0 & 0 & 0 & 0.74 & 0.73 \\
\hline T16.6 & 2 & 1 & 1 & 1 & 2 & 1 & 1 & 2 & 1 & 1 & 1 & 0 & 0 & 2 & 3 & 3 & 0 & 0 & 1 & 1.23 & 0.92 \\
\hline T16.7 & 1 & 1 & 1 & 1 & 1 & 1 & 1 & 1 & 1 & 2 & 1 & 0 & 0 & 0 & 3 & 3 & 1 & 1 & 0 & 1.05 & 0.85 \\
\hline T16.8 & 2 & 2 & 2 & 2 & 2 & 2 & 2 & 2 & 1 & 3 & 1 & 2 & 1 & 3 & 1 & 3 & 1 & 1 & 2 & 1.84 & 0.69 \\
\hline T16.9 & 2 & 1 & 1 & 1 & 1 & 1 & 1 & 1 & 1 & 1 & 0 & 0 & 0 & 0 & 0 & 0 & 0 & 3 & 2 & 0.84 & 0.83 \\
\hline T16.10 & 1 & 2 & 2 & 2 & 2 & 2 & 2 & 1 & 1 & 2 & 1 & 1 & 0 & 2 & 3 & 3 & 1 & 3 & 1 & 1.68 & 0.82 \\
\hline T16.A & 3 & 2 & 2 & 2 & 1 & 2 & 1 & 1 & 3 & 2 & 1 & 0 & 0 & 1 & 1 & 1 & 1 & 0 & 1 & 1.32 & 0.89 \\
\hline T16.B & 1 & 1 & 1 & 1 & 1 & 1 & 1 & 1 & 1 & 1 & 0 & 0 & 0 & 3 & 1 & 1 & 1 & 0 & 0 & 0.84 & 0.69 \\
\hline $\begin{array}{c}\text { MEA } \\
\mathbf{N}\end{array}$ & $\begin{array}{l}1 . \\
50\end{array}$ & $\begin{array}{l}1 . \\
25\end{array}$ & $\begin{array}{l}1 . \\
25\end{array}$ & $\begin{array}{l}1 . \\
25\end{array}$ & $\begin{array}{l}1 . \\
50\end{array}$ & $\begin{array}{l}1 . \\
42\end{array}$ & $\begin{array}{l}1 . \\
25\end{array}$ & $\begin{array}{l}0 . \\
92\end{array}$ & $\begin{array}{l}1 . \\
17\end{array}$ & $\begin{array}{l}1 . \\
42\end{array}$ & $\begin{array}{l}\text { 0. } \\
50\end{array}$ & $\begin{array}{l}0 . \\
25\end{array}$ & $\begin{array}{l}0 . \\
17\end{array}$ & $\begin{array}{l}1 . \\
17\end{array}$ & $\begin{array}{l}1 . \\
25\end{array}$ & $\begin{array}{l}1 . \\
42\end{array}$ & $\begin{array}{l}0 . \\
42\end{array}$ & $\begin{array}{l}0 . \\
67\end{array}$ & $\begin{array}{l}0 . \\
58\end{array}$ & 1.02 & $\begin{array}{l}\text { SDG } \\
\mathbf{1 6} \\
\mathrm{t}=-1 \\
4.83 \\
\mathrm{p}=0 . \\
00\end{array}$ \\
\hline SD & $\begin{array}{l}0 . \\
67\end{array}$ & $\begin{array}{l}0 . \\
45\end{array}$ & $\begin{array}{l}0 . \\
45\end{array}$ & $\begin{array}{l}0 . \\
45\end{array}$ & $\begin{array}{l}0 . \\
52\end{array}$ & $\begin{array}{l}0 . \\
51\end{array}$ & $\begin{array}{l}0 . \\
45\end{array}$ & $\begin{array}{l}0 . \\
67\end{array}$ & $\begin{array}{l}0 . \\
58\end{array}$ & $\begin{array}{c}0 . \\
90\end{array}$ & $\begin{array}{c}0 . \\
59\end{array}$ & $\begin{array}{l}0 . \\
61\end{array}$ & $\begin{array}{l}0 . \\
68\end{array}$ & $\begin{array}{c}0 . \\
70\end{array}$ & $\begin{array}{l}0 . \\
78\end{array}$ & $\begin{array}{l}0 . \\
86\end{array}$ & $\begin{array}{l}0 . \\
94\end{array}$ & $\begin{array}{l}0 . \\
94\end{array}$ & $\begin{array}{c}0 . \\
98\end{array}$ & 0.88 & $\begin{array}{l}\text { SDG } \\
\mathbf{1 7} \\
\mathrm{t}=-1 \\
9.52 \\
\mathrm{p}=0 . \\
00\end{array}$ \\
\hline
\end{tabular}

The highest mean score (highest level of compatibility) for SDG16 as a goal compared to the SDG17 targets were for SDG17 Targets 1 and 5 at $1.50 \pm 0.67$ and 1.50 \pm 0.52 . On the other hand, comparing SDG17 as a goal to the targets of SDG16, SDG16 Targets 8 scored $1.84 \pm 0.69$ which was the highest and therefore the most compatible SDG16 targets with SDG17. When the one sample t-test was computed with a test value of +3 , the SDG16 had a mean significantly differed from the test value $(\mathrm{t}=-14.83, \mathrm{p}=0.00)$ and a similar result was obtained for SDG17 which had a significant difference from the test value $(\mathrm{t}=-19.52, \mathrm{p}=0.00)$.

\subsection{Summary of SDG16 Targets Vs the other SDGs (Compatibility Analysis)}

Table 20: Showing Compatibility Scores of SDG16 Targets with the 16 Other Sustainable Development Goals (Summary of Tables 4 To 19)

\begin{tabular}{|c|c|c|c|c|c|c|c|c|c|c|c|c|c|c|c|c|c|c|}
\hline \multirow[b]{2}{*}{ SDG 16} & \multicolumn{16}{|c|}{ SUSTAINABLE DEVELOPMENT GOALS } & \multirow{2}{*}{$\begin{array}{l}\text { MEA } \\
\mathbf{N}\end{array}$} & \multirow[b]{2}{*}{ SD } \\
\hline & 1 & 2 & 3 & 4 & 5 & 6 & 7 & 8 & 9 & 10 & 11 & 12 & 13 & 14 & 15 & 17 & & \\
\hline \multirow[b]{2}{*}{ SDG16.1 } & 1.0 & 0.2 & 1.2 & 0.8 & 1.5 & 1.1 & 0.0 & 0.4 & 0.5 & 1.2 & 1.2 & 0.5 & 1.0 & 0.4 & 0.6 & 0.4 & \multirow[b]{2}{*}{0.77} & \multirow[b]{2}{*}{0.43} \\
\hline & 0 & 9 & 3 & 0 & 6 & 3 & 0 & 2 & 0 & 0 & 0 & 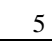 & 0 & 0 & 7 & 2 & & \\
\hline \multirow[b]{2}{*}{ SDG16.2 } & 1.1 & 0.1 & 1.2 & 1.1 & 1.4 & 0.0 & 0.0 & 0.5 & 0.2 & 1.2 & 0.4 & 0.4 & 0.0 & 0.0 & 0.0 & 0.4 & \multirow[b]{2}{*}{0.52} & \multirow[b]{2}{*}{0.52} \\
\hline & 4 & 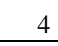 & 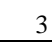 & 0 & 4 & 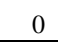 & . & 0 & 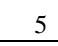 & 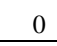 & 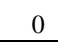 & 5 & 0 & 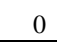 & 0 & 2 & & \\
\hline \multirow[b]{2}{*}{ SDG16.3 } & 1.1 & 0.1 & 1.3 & 1.8 & 2.3 & 1.6 & 1.0 & 1.8 & 1.7 & 1.8 & 1.3 & 1.2 & 1.4 & 1.3 & 1.3 & 1.2 & \multirow[b]{2}{*}{1.41} & \multirow[b]{2}{*}{0.48} \\
\hline & 4 & 4 & 1 & 0 & 3 & 3 & 0 & 3 & 5 & 0 & 0 & 7 & 0 & 0 & 3 & 6 & & \\
\hline \multirow[b]{2}{*}{ SDG16.4 } & 0.8 & 0.0 & 0.8 & 1.0 & 1.4 & 0.3 & 0.0 & 0.6 & 0.2 & 0.6 & 0.2 & 0.5 & 0.0 & 0.0 & 0.0 & 0.5 & \multirow[b]{2}{*}{0.46} & \multirow[b]{2}{*}{0.43} \\
\hline & 6 & 0 & 5 & 0 & 4 & 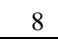 & 0 & 7 & 5 & . & 0 & 5 & 0 & 0 & 0 & 8 & & \\
\hline \multirow[b]{2}{*}{ SDG16.5 } & 0.2 & 0.1 & 0.3 & 0.9 & 0.2 & 0.3 & 0.6 & 0.7 & 0.2 & 0.7 & 0.0 & 0.8 & 0.0 & 0.0 & 0.0 & 0.7 & \multirow[b]{2}{*}{0.38} & \multirow[b]{2}{*}{0.32} \\
\hline & 9 & 4 & 1 & 0 & 2 & 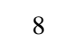 & 0 & 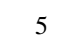 & 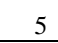 & 0 & 0 & 2 & 0 & 0 & 0 & 4 & & \\
\hline \multirow[b]{2}{*}{ SDG16.6 } & 1.0 & 0.4 & 1.9 & 2.1 & 2.1 & 1.7 & 1.6 & 1.9 & 1.6 & 2.0 & 0.9 & 1.4 & 1.0 & 1.0 & 1.2 & 1.2 & \multirow[b]{2}{*}{1.46} & \multirow[b]{2}{*}{0.50} \\
\hline & 0 & 3 & 2 & 0 & 1 & 5 & 0 & 2 & 3 & 0 & 0 & 5 & 0 & 0 & 5 & 3 & & \\
\hline \multirow[b]{2}{*}{ SDG16.7 } & 0.8 & 0.5 & 1.0 & 1.6 & 2.1 & 1.5 & 1.0 & 1.4 & 1.2 & 1.3 & 0.7 & 1.0 & 0.8 & 0.9 & 1.0 & 1.0 & \multirow[b]{2}{*}{1.14} & \multirow[b]{2}{*}{0.38} \\
\hline & 6 & 7 & 8 & 0 & 1 & 0 & 0 & 2 & 5 & 0 & 0 & 9 & 0 & 0 & 0 & 5 & & \\
\hline \multirow[b]{2}{*}{ SDG16.8 } & 0.5 & 0.4 & 1.2 & 1.7 & 2.3 & 1.7 & 1.8 & 2.1 & 2.0 & 2.0 & 1.4 & 1.9 & 1.8 & 1.5 & 2.0 & 1.8 & \multirow[b]{2}{*}{1.65} & \multirow[b]{2}{*}{0.53} \\
\hline & 7 & 3 & 3 & 0 & 3 & 5 & 0 & 7 & 0 & 0 & 0 & 1 & 0 & 0 & 0 & 4 & & \\
\hline \multirow[b]{2}{*}{ SDG16.9 } & 0.2 & 0.2 & 0.3 & 0.5 & 0.0 & 0.0 & 0.4 & 0.2 & 0.1 & 1.0 & 0.5 & 0.1 & 0.0 & 0.0 & 0.0 & 0.8 & & \\
\hline & 9 & 9 & 8 & 0 & 0 & 0 & 0 & 5 & 3 & 0 & 0 & 8 & 0 & 0 & 0 & 4 & 0.30 & 0.30 \\
\hline SDG16.1 & 1.0 & 0.7 & 1.5 & 2.1 & 2.5 & 1.3 & 1.8 & 1.6 & 1.7 & 1.9 & 1.6 & 1.3 & 2.0 & 1.2 & 1.5 & 1.6 & 1.61 & 0.44 \\
\hline
\end{tabular}




\begin{tabular}{|c|c|c|c|c|c|c|c|c|c|c|c|c|c|c|c|c|c|c|}
\hline 0 & 0 & 1 & 4 & 0 & 6 & 8 & 0 & 7 & 5 & 0 & 0 & 6 & 0 & 0 & 0 & 8 & & \\
\hline SDG16.1 & 0.8 & 0.1 & 1.0 & 1.4 & 1.6 & 1.1 & 1.2 & 1.5 & 1.1 & 1.8 & 1.2 & 0.9 & 1.0 & 1.2 & 0.4 & 1.3 & & \\
\hline 1 & 6 & 4 & 8 & 0 & 7 & 3 & 0 & 8 & 3 & 0 & 0 & 1 & 0 & 0 & 2 & 2 & 1.13 & 0.42 \\
\hline SDG16.1 & 1.1 & 1.0 & 1.5 & 2.0 & 2.7 & 1.8 & 1.8 & 1.7 & 1.7 & 1.8 & 1.4 & 1.0 & 0.8 & 0.0 & 0.2 & 0.8 & & \\
\hline 2 & 4 & 0 & 4 & 0 & 8 & 8 & 0 & 5 & 5 & 0 & 0 & 9 & 0 & 0 & 5 & 4 & 1.36 & 0.70 \\
\hline MEAN & $\begin{array}{c}0.8 \\
5\end{array}$ & $\begin{array}{c}0.3 \\
6\end{array}$ & $\begin{array}{c}1.1 \\
4\end{array}$ & $\begin{array}{c}1.4 \\
2\end{array}$ & $\begin{array}{c}1.7 \\
1\end{array}$ & $\begin{array}{c}1.0 \\
7\end{array}$ & $\begin{array}{c}0.9 \\
3\end{array}$ & $\begin{array}{c}1.2 \\
4\end{array}$ & $\begin{array}{c}1.0 \\
5\end{array}$ & $\begin{array}{c}1.4 \\
4\end{array}$ & $\begin{array}{c}0.9 \\
0\end{array}$ & $\begin{array}{c}0.9 \\
7\end{array}$ & $\begin{array}{c}0.8 \\
2\end{array}$ & $\begin{array}{c}0.6 \\
3\end{array}$ & $\begin{array}{c}0.7 \\
0\end{array}$ & $\begin{array}{c}1.0 \\
2\end{array}$ & 1.02 & $\begin{array}{l}\text { SDG1 } \\
\mathbf{6} \\
\mathrm{t}=-13.6 \\
6 \\
\mathrm{p}=0.00\end{array}$ \\
\hline SD & $\begin{array}{c}0.3 \\
1\end{array}$ & $\begin{array}{c}0.2 \\
9\end{array}$ & $\begin{array}{c}0.4 \\
6\end{array}$ & $\begin{array}{c}0.5 \\
5\end{array}$ & $\begin{array}{c}0.8 \\
7\end{array}$ & $\begin{array}{c}0.7 \\
0\end{array}$ & $\begin{array}{c}0.7 \\
3\end{array}$ & $\begin{array}{c}0.6 \\
8\end{array}$ & $\begin{array}{c}0.7 \\
3\end{array}$ & $\begin{array}{c}0.5 \\
1\end{array}$ & $\begin{array}{c}0.5 \\
3\end{array}$ & $\begin{array}{c}0.4 \\
9\end{array}$ & $\begin{array}{c}0.7 \\
1\end{array}$ & $\begin{array}{c}0.6 \\
1\end{array}$ & $\begin{array}{c}0.7 \\
0\end{array}$ & $\begin{array}{c}0.4 \\
6\end{array}$ & 0.66 & $\begin{array}{l}\text { SDG } \\
\mathrm{t}=-23.8 \\
4 \\
\mathrm{p}=0.00\end{array}$ \\
\hline
\end{tabular}

Information in Table 20 are means from the individual entries for each SDG16 targets with the targets of the various 16 other SDGs. Detailed data used to generate the information above are found in Tables 4 to 19.

Using a 7-point assessment scale, where 3 is the most compatible, 0 indicates no relationship and -3 showing most negative and counterproductive relationships, we can say that any score above 1 shows a good degree of interdependency or good relationship. Meaning that, the pair of targets being evaluated is complementary and that the two aspirations are supportive to each other. Based on that premise, we can deduct the following:

- SDG16 target 1 is highly complementary to the collated scores of SDGs, 1, 3, 5, 6, 10, 11 and 13.

- SDG16 target 2 is highly complementary to the collated scores of SDGs 1, 2, 3, 4, 5, and 10.

- SDG16 target 3 is highly compatible to the collated scores of all the SDGs except SDG2. The score for SDG5 was as high as 2.33 in a scale with a maximum mean score of 3.

- The SDG16 target 4 is highly compatible to the collated scores of only SDGs 4 and 5.

- The SDG16 target 5 is not highly compatible to the collated scores of all the SDGs.

- The SDG16 target 6 is highly compatible to the collated scores of all the SDGs especially 4, 5 and 10. However it is not compatible to SDG2.

- The SDG16 target 7 is highly compatible to the collated scores of all the SDGs except 1, 2, 11, 13 and 14. The score for SDG7 is as high as 2.11.

- The SDG16 target 8 is highly compatible to all the SDGs except SDGs 1 and 2. The scores were above 2 for $5,8,9,10$ and 15 .

- The SDG16 target 9 is highly compatible to only SDG 10.

- The SDG16 target 10 is highly compatible to all the SDGs except SDG2. The scores for SDGs 4, 5 and 13 were above 2.

- The SDG16 target 11 is highly compatible to all the SDGs except SDGs 1 and 15.

- The SDG16 target 12 is highly compatible to all the SDGs except SDGs 13,14, 15 and 17 . While the target for SDG4 is 2, SDG5 had a score of 2.78 which is close to the maximum possible score of 3.

It is noteworthy that we did not observe any negative relationships (-1 to -3$)$ between SDG16 targets with the other 16 SDGs in all the tables (Tables 4 to 19). The least score was 0 (Zero) while the highest score was the maximum (+3).

Most often because of the positive nature of how targets and goals are worded, evaluations at the targets and goal levels do not generate counterproductive relations. However, there are few exceptions, but none exists when comparing SDG16 with the other SDGs. Some of such include SDG11 target 2 which refers to increase in the construction of infrastructure, roads, and railways as against SDG15 that is aimed at maintaining biodiversity and protection of the remaining forest systems seems to have some level of disharmony that must be carefully managed. Another example is SDG2 (Zero Hunger) target 3 which refers to doubling agricultural productivity implying increase in acreage under cultivation and increase in the use of pesticides, fertilizers etc. It is noteworthy that increase in the use of these substances will negatively impact some of the targets of SDGs 14 and 15 and the increase in the land under cultivations will also necessitate clearing of more forest lands for the purpose of agriculture. Equally the first and the last targets of SDG 7 can be misconstrued to mean large scale provision of energy mix to meet the needs of energy supply deficient countries, as this is counterproductive to aspects of 


\section{SDG13 on Climate Action.}

Synergistic or counter-productive indications are often more prominent when evaluating the relationships of interventions derived from addressing a target/goal with other targets or goals. Interventionists should therefore always evaluate how the proposed interventions impact on other SDGs and priority should be given to those that have positive synergy and are impacting many goals at the same time.

\subsection{Goals Compatibility Analysis}

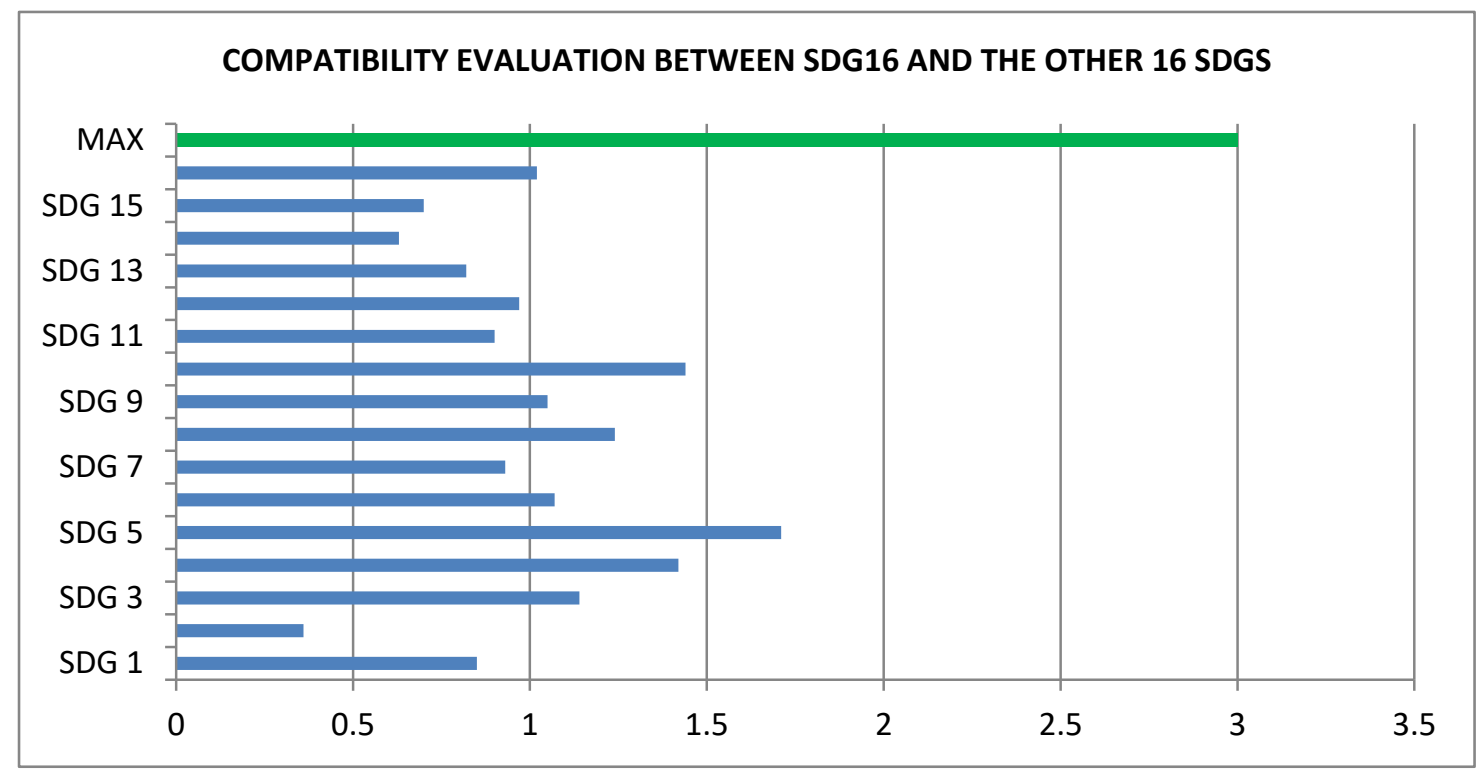

Figure 1. Compatibility evaluation between SDG16 and the other 16 SDGs

Source: Researchers' Desk (2020).

Figure 1 shows that SDG16 has the highest compatibility score with SDG5 followed by SDGs 4 and 10. The targets from which SDG16 were derived have least compatibility factor with the targets from which SDG2 were derived.

Our analysis based on the targets set for each SDG, showed that SDG5 which is about improving Gender inequality, SDG 4 which is about improving education, SDG8 which is to improve jobs, and SDG10 which is aimed at reducing inequality among nations are the most compatible with SDG16 which is aimed at fostering global amity and creating enabling conditions for global peace.

\subsection{Compatibility Analysis between SDG16 Targets and All the Other Goals}

Compatibility evaluation between SDG16 targets and the cumulative effects on other 16 SDGs 


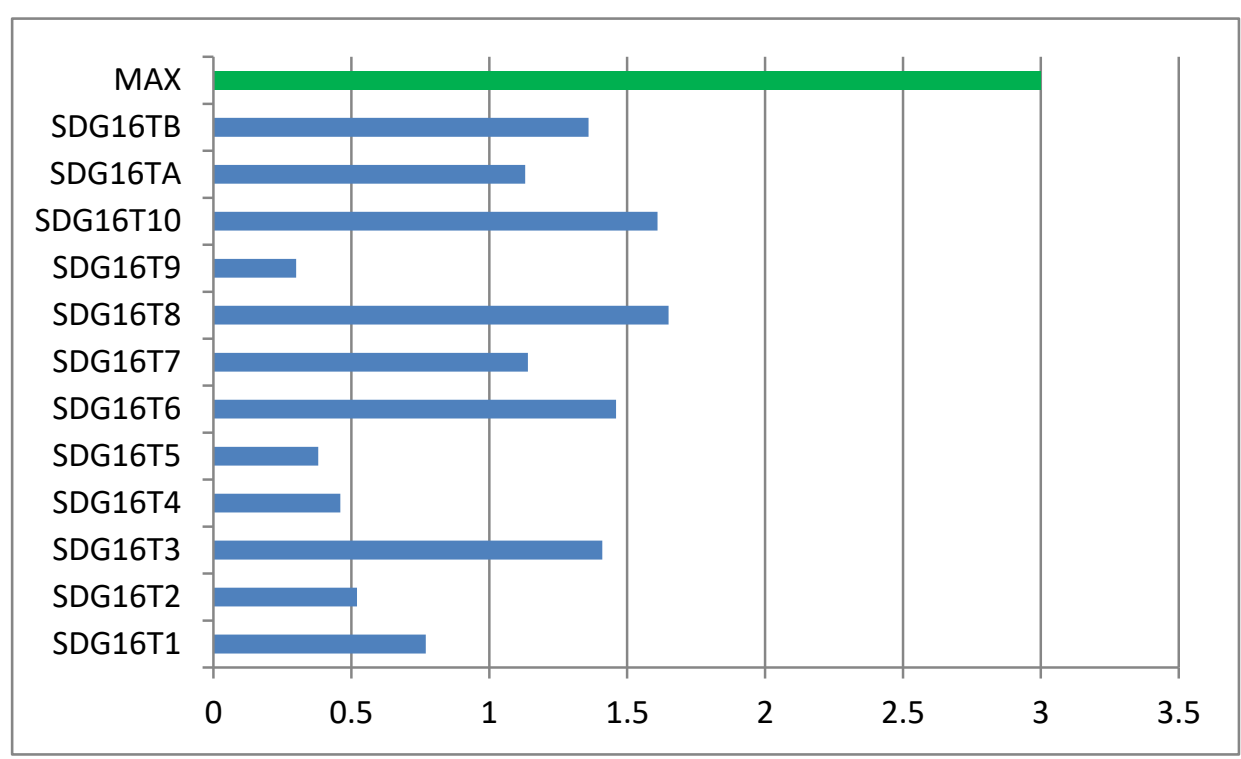

Figure 2. Compatibility evaluation between SDG16 targets and the cumulative effects on other 16 SDGs Source: Researchers’ Desk (2020).

Figure 2 shows that SDG16 targets 8,10,6,13 and B are the most compatibly aligned with aspirations of all the SDGs holistically. SDG targets 9 and 5 are the least aligned followed by SDG16 targets 4 and 2.

\section{Conclusion and Recommendation}

The aspirations embedded in the development of SDG2 targets and those of SDG16 were least aligned as can be seen with the mean score of 0.36 in Table 20. This pair is the least compatible followed by the pairs of SDG16 and SDG14 (mean scores 0.63) and SDG16 and SDG15 (mean score 0.70). SDG16 and SDG5 were the most aligned followed by SDG16 and SDG10 (Table 20 and Figure 1).

SDG16 targets 8, 10, 6, 13 and B are the most compatibly aligned with aspirations of all the SDGs holistically. SDG targets 9 and 5 are the least aligned followed by SDG16 targets 4 and 2.

The overall mean score of all the data in Table 20 (inter-linking cell of the last column and last row) is 1.02 as against a possible maximum score of 3. This means that SDG16 is reasonably well aligned with all the other SDGs put together.

The implication of these findings is that the formulations of goals for SDG2, SDG14 and SDG15 when related to the aspirations of SDG16 are not well aligned and would need to be looked at during subsequent reviews (may be at the expiration of the SDG implementation phase in 2030) in a way that some of the component targets of these goals are transformed or modified with the aimed at enhancing the achievements of the aspirations by making the goals become more aligned and integrated among the SDGs. This will enhance the effectiveness in the achievement of the overall goal aspirations and general philosophies on which these goals and driving targets were embedded and formulated.

There has been a remarkable work done on the qualitative analysis of inter-relatedness of SDGs and complementing such works with this type of quantitative analysis will give a more robust assessment of how compatible and aligned SDGs are to each other.

This application is not only useful to compare or assess alignments and compatibilities between a target and another, between targets and goals and between goals of SDGs, it is equally useful and applicable to assess compatibilities and alignments of other elaborate strategic policy designs having many targets, objectives and goals.

We therefore recommend as follows:

1. Increased multi-sectorial stakeholders' involvement (at all fronts of development planning and other programmes having multifaceted strategic plans) should be encouraged, as a way towards enhancing the achievement of set goals and also enhancing effective achievement of all such policy formulations involving setting targets/objectives and goals. 
2. UN may review these SDG targets subsequently in a way that every SDG is aligned and supportive of the other SDGs as much as possible to enhance synergy and positive multiplier effects.

\section{References}

Griggs, D. M., Stafford, S. J., Rockström, M. C., Öhman, O., Gaffney, G., Glaser, N., ... Shyamsundar, P. (2014). An Integrated Framework for Sustainable Development Goals. Ecology and Society, 19(4), 49. https://doi.org/10.5751/ES-07082-190449

International Council for Science Union. (2017). A Guide to SDG interactions: from science to implementation. Council Science. Paris.

Lawrence, A. W., Ihebuzor, N., \& Lawrence, D. O. (2020). Macro-Level Studies of Direct and Indirect Relationships between SDG 4 and the 16 SDGS. Modern Economy. Scientific Research Publishing, 11. ISSN: 2152-7261). https://doi.org/10.4236/me.2020.116085

McCollum, D., Echeverri, L., Busch, S., Pachauri, S., Parkinson, S., Rogelj, J., ... Stevance, A. S. (2018) Connecting the sustainable development goals by their energy inter-linkages. Environmental Research Letters. https://doi.org/10.1088/1748-9326/aaafe3

Nilsson, M., Griggs, D., \& Visbeck, M. (2016). Map the interactions of sustainable development goals. Nature, 534, 320-322. https://doi.org/10.1038/534320a

Senge, P. M. (1990). The Fifth Discipline D. Company, ed., Doubleday.

United Nations Development Program. (2017).SDG Accelerator and Bottleneck Assessment. One United Nations Plaza, UNDP, New York.

United Nations Development Program. (2019). Enabling the implementation of the 2030 Agenda through SDG 16+ - anchoring Peace, Justice and Inclusion. Global Alliance. United Nations, New York.

United Nations. (2020). Sustainable Development Goals. Retrieved from https://www.un.org/sustainabledevelopment/sustainable-development-goals/

Weitz, N., Carlsen, H., Nilsson, M., \& Skånberg, K. (2017). Towards systemic and contextual priority setting for implementing the 2030 Agenda. SustainaSci, 13, 531-548. https://doi.org/10.1007/s11625-017-0470-0

\section{Copyrights}

Copyright for this article is retained by the author(s), with first publication rights granted to the journal.

This is an open-access article distributed under the terms and conditions of the Creative Commons Attribution license (http://creativecommons.org/licenses/by/4.0/). 